\title{
Recharge processes within the Cacapon Mountain Aquifer, Ridge and Valley Province, West Virginia
}

Cristine M. Vinciguerra

West Virginia University

Follow this and additional works at: https://researchrepository.wvu.edu/etd

\section{Recommended Citation}

Vinciguerra, Cristine M., "Recharge processes within the Cacapon Mountain Aquifer, Ridge and Valley Province, West Virginia" (2008). Graduate Theses, Dissertations, and Problem Reports. 4429. https://researchrepository.wvu.edu/etd/4429

This Thesis is protected by copyright and/or related rights. It has been brought to you by the The Research Repository @ WVU with permission from the rights-holder(s). You are free to use this Thesis in any way that is permitted by the copyright and related rights legislation that applies to your use. For other uses you must obtain permission from the rights-holder(s) directly, unless additional rights are indicated by a Creative Commons license in the record and/ or on the work itself. This Thesis has been accepted for inclusion in WVU Graduate Theses, Dissertations, and Problem Reports collection by an authorized administrator of The Research Repository @ WVU. For more information, please contact researchrepository@mail.wvu.edu. 
Recharge Processes within the Cacapon Mountain Aquifer, Ridge and Valley Province, West Virginia

\author{
Cristine M. Vinciguerra
}

\author{
Thesis submitted to the \\ Eberly College of Arts and Sciences \\ at West Virginia University \\ in partial fulfillment of the requirements \\ for the degree of \\ Master of Science \\ in \\ Geology \\ Joseph Donovan, Ph.D., Chair \\ Eberhard Werner, M.S. \\ Dorothy Vesper, Ph.D. \\ Department of Geology
}

Morgantown, West Virginia 2008 


\begin{abstract}
Recharge Processes within the Cacapon Mountain Aquifer, Ridge and Valley Province, West Virginia
\end{abstract}

\title{
Cristine M. Vinciguerra
}

During the 2006-2007 water year, apparent recharge rates for three streams draining the Cacapon Mountain Aquifer, in the Valley and Ridge Province of northern West Virginia, were estimated using hydrograph separation techniques. The techniques use stream baseflow, dominated by groundwater discharge, as a surrogate for groundwater recharge. Two of the streams draining the aquifer were strike-normal (Rock Gap Run and Breakneck Run) and one was strike-parallel (Sir Johns Run). The strikenormal streams had significantly lower apparent recharge rates (Rock Gap Run: 2.52 in/yr; Breakneck Run: 6.57 in/yr) than the strike-parallel stream (Sir Johns Run: 13.31 $\mathrm{in} / \mathrm{yr}$ ). The large variations in recharge rate are interpreted to be due to water lost to the Helderberg Limestone, a local conduit-forming unit, in the two former drainages. In this particular geologic setting, apparent recharge rates of strike-parallel and strike-normal streams draining the same aquifer may differ substantially. Estimating recharge rates from stream flow data may give inaccurate numbers if the stream flows over highly transmissive conduit forming limestone or extensive fractures. 


\section{Acknowledgments}

I would like to thank my committee Joe Donovan, Dorothy Vesper, and Eb Werner for their time and effort put into serving on this committee. I would like to offer special thanks to Joe Donovan and Eb Werner for getting me through this process in one piece. Thank you to my roommates and friends Matt, Jane, and Dan for acting as impromptu field assistants whenever I needed you. I am additionally thankful to everyone in Morgan County especially Jack and Alma. Last but not least thank you to Breccia and Gabbro, your unconditional love during this process has been greatly appreciated. 


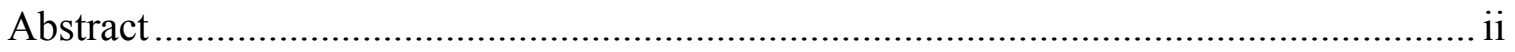

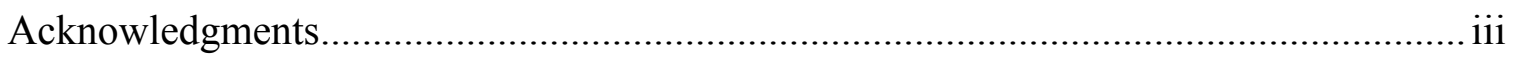

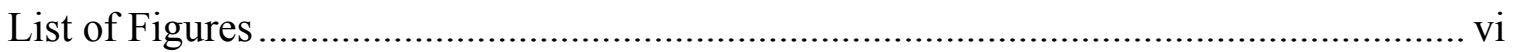

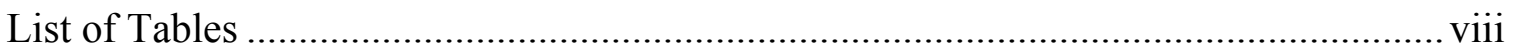

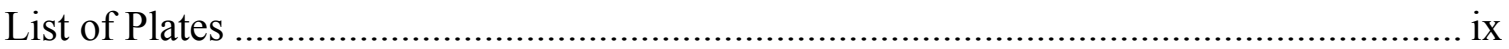

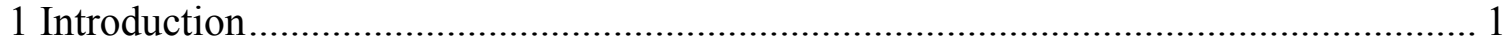

1.2 Purpose

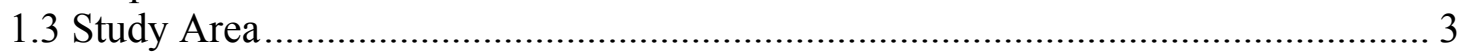

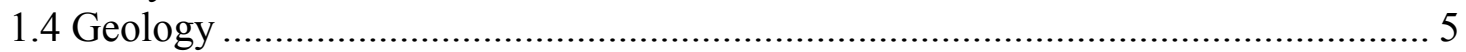

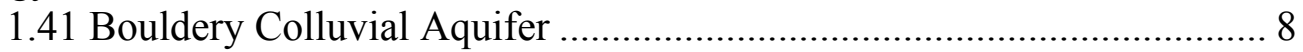

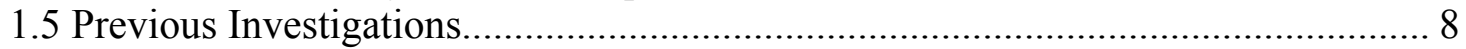

2 Elements of hydrograph analysis for recharge estimation........................................... 11

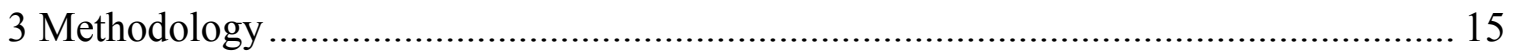

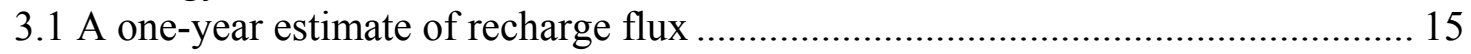

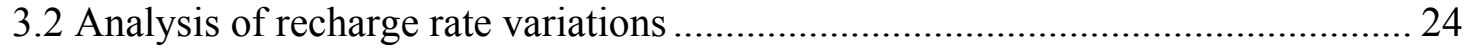

3.21 Cacapon Mountain aquifer.................................................................. 24

3.22 Montane and lowland karst (humid east).......................................... 24

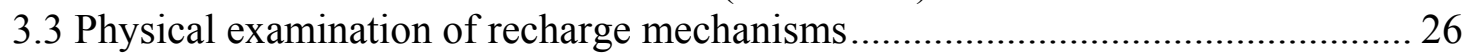

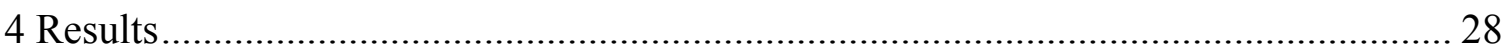

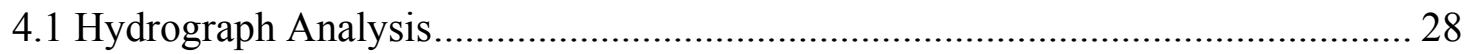

4.12 Multiple Recession Slopes ............................................................... 28

4.2 Recharge rate for Cacapon Mountain Aquifer ...................................................... 31

4.21 Variations between Cacapon Mountain drainages................................... 31

4.22 Differences between baseflow-separation methods:............................... 36

4.3 Spatial variations in recharge rates within the Cacapon Mountain Aquifer............ 36

4.4 Comparison of recharge rates to other regional aquifers ………........................... 39

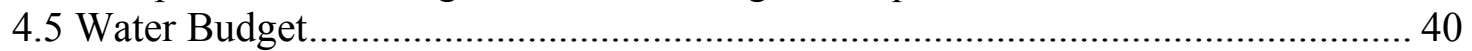

4.6 Recharge Mechanisms of the Aquifer .................................................................. 40

4.61 Hydrogeology of Cold Run Valley ......................................................... 40

4.62 Seepage run along Rock Gap Run ..................................................... 44

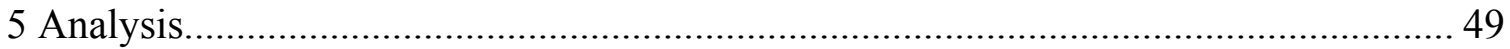

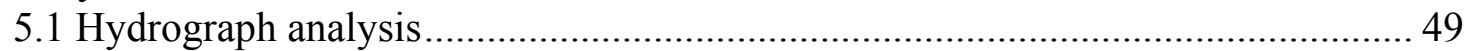

5.2 Methods for recharge rate estimation.................................................................. 58

5.3 Local spatial variations in recharge rate ............................................................... 59

5.4 Comparison of recharge rates to other aquifers in the humid east ......................... 61 


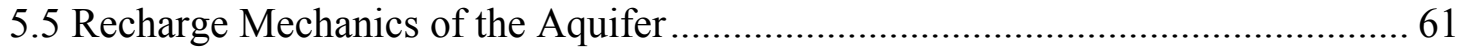

5.51 Structural and Geomorphic effects .................................................. 61

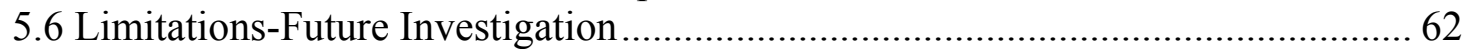

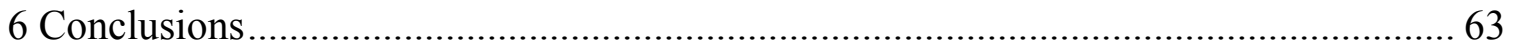

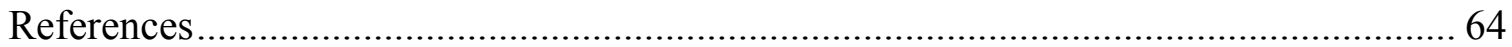




\section{List of Figures}

Figure 1. Location map of the Cacapon Mountain aquifer, Morgan County, WV ............ 4

Figure 2. Shaded relief map of Cold Run Valley from the $10 \mathrm{~m}$ digital elevation model

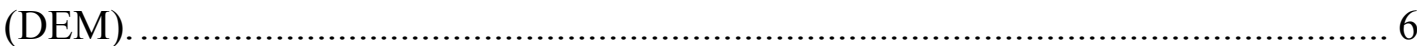

Figure 3. Geology of Cacapon Mountain aquifer after Grimsley (1916). ......................... 9

Figure 4. Recharge pathways for Cold Run Valley, after Houston (2002), Figure 9..... 10

Figure 5. Stream hydrograph from a Mid-April storm event on Rock Gap Run............ 14

Figure 6. Installing stilling well at Rock Gap Run, July 2006 (photo Matt Finkenbinder).

Figure 7. Rating curves for (a) Breakneck Run, (b) Rock Gap Run, and (c) Sir Johns

Run.

Figure 8. Typical Breakneck Run discharge hydrograph, showing slopes of storm runoff

and baseflow components.

Figure 9. Calculating recharge using the recession curve displacement method, after

Rutledge (1993).

Figure 10. Rock Gap Run was cropped at $0.25 \mathrm{cfs}$, the detection limit of the flow meter.

Figure 11. Raw total pressure data for Rock Gap Run and Breakneck Run from July 2006-July 2007

Figure 12. Streams catchments for which recharge rates were calculated in this study,

Eastern Panhandle, WV. USGS gageing stations denoted with red stars.

Figure 13. Location of Tonoloway Spring in the Cacapon Mountain Aquifer.

Figure 14. Hydrographs from Rock Gap Run and Tonoloway Spring, showing three

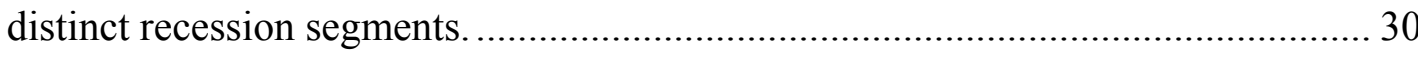

Figure 15. Base flow separation, Sir Johns Run......................................................... 32

Figure 16. Base flow separation, Rock Gap Run............................................................ 33

Figure 17. Base flow separation, Breakneck Run........................................................ 34

Figure 18. Cumulative precipitation versus time for Cacapon State Park and the

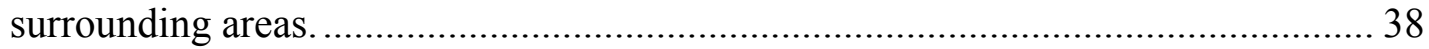

Figure 19. Lineament spacing in the Rock Gap Run watershed................................. 42 
Figure 20. Digital elevation model of Cold Run Valley, Lineaments traced in white. ... 43

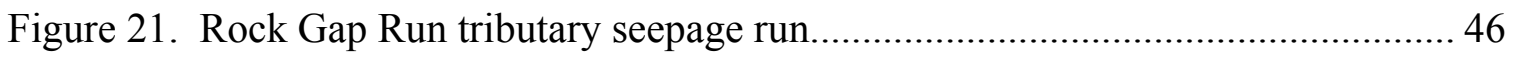

Figure 22. Results of seepage run performed on April $25^{\text {th }} 2007$ on Rock Gap Run...... 47

Figure 23. Streams in the Valley and Ridge physiographic province used for statistical

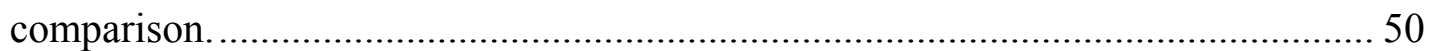

Figure 24. Whisker plot of normalized recharge values for sample streams in the Valley and Ridge showing relationship of study area streams. Legend: RGR = Rock Gap Run, BNR = Breakneck Run, SJR = Sir Johns Run. ..................................... 56 


\section{List of Tables}

Table 1. Flow components for the streams in Cold Run Valley.................................. 35

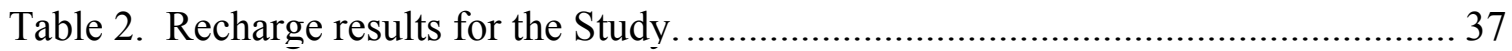

Table 3. Results from seepage run number 1 on Rock Gap Run................................. 45

Table 4. Baseline data for streams in the Valley and Ridge physiographic province. .... 51

Table 5. Results of a T-Test comparing the means of the normalized recharge between the streams in Cold Run Valley and the sample streams from the Valley and Ridge.

Table 6. T-Test results for the upper and lower confidence limits of normalized recharge for the sample streams from the Valley and Ridge............................................ 53

Table 7. Results of a T-Test comparing the means of the normalized recharge between the strike normal streams in Cold Run Valley and the sample streams from the Valley and Ridge.

Table 8. Flow proportions for study streams in West Virginia's eastern panhandle. 


\section{List of Plates}

Plate 1. Geology and Hydrology of the Cacapon Mountain aquifer.......................68 


\section{Introduction}

Recharge is any addition of water to an aquifer via vertical infiltration to the water table, occurring as a result of either natural processes or anthropogenic influences (Kellers, 1996). Over large periods of time, recharge is equal to groundwater discharge minus evapotranspiration and utilization, plus or minus any change in aquifer storage (Rutledge, 1998). As a result, groundwater discharge measurements are frequently the basis for estimation of groundwater recharge.

Groundwater discharge from karst aquifers commonly differs in flow mechanisms from that of clastic aquifers. Much of the discharge from karst aquifers is from concentrated outflows (e.g., springs), with a "quickflow" (Atkinson, 1977) component, in addition to the more diffuse discharge directly to streams that dominates non-karstic aquifers (White, 1988). Measuring baseflow recession of streams sustained by a karst aquifer utilizes both concentrated and diffuse flow components to assess total recharge (Meyboom, 1961). Hydrographs of baseflow recession may be fitted using an exponential decline with respect to time, yielding a parameter that describes recession rate (Vogel and Kroll, 1996).

In montane karst aquifers, both recharge and discharge rates can differ in magnitude from those in lowland settings (Petric, 2004). Relatively deformed and/or faulted strata often underlie montane karst settings. Steeply sloping topography allows for the potential for higher hydraulic gradients, and correspondingly higher flow rates than in areas of low relief. Montane karst settings also tend to have elevated recharge rates as a result of greater precipitation, greater snow pack and/or decreased evapotranspiration. 
Factors affecting recharge to any aquifer are rates of runoff, snowmelt, precipitation, infiltration, vadose and phreatic evapotranspiration, pumping, and stream loss to the aquifer (Petric, 2001). Recharge can occur both through and outside of sinkholes (Petric, 2001). Montane karst aquifers exhibit discharge time series that are very similar to time series of precipitation except during the spring months when discharges are normally highest due to snowmelt and increased precipitation (Petric, 2001).

Recharge to karst aquifers may occur either as quickflow or as matrix flow. Quickflow can refer to conduit flow, induced when runoff flows directly into a sinkhole or sinking stream reach (Felton, 1994) but can also refer to other accelerated pathway to the water table. It may also represent bank storage effects that have little to do with groundwater. Matrix flow represents water moving through the aquifer through openings at lower velocity. Information about flow and storage characteristics of an aquifer can be obtained through studying the recharge-discharge relationship of that aquifer (Petric, 2001).

Measurement of recharge rates is necessary to quantify the amount of inflow to an aquifer. A better understanding of the aquifer's recharge rate is a required to develop groundwater flow models.

Estimating recharge from streamflow records assumes negligible underflow because of that the term apparent recharge rate will be used to describe the recharge rate estimated from streamflow. 


\subsection{Purpose}

The purpose of this study is to estimate recharge to an eastern montane karst aquifer and to compare its observed recharge characteristics - including rate, spatial variability, and temporal variability -- to geologically similar eastern U.S. settings. This involved the following objectives:

- Objective 1. A one-year (2006-2007) estimate of apparent recharge flux to the aquifer, performed by time-integration of groundwater discharge

- Objective 2. Testing of the hypothesis that there is a significant difference in apparent recharge rates between (a) different portions of the Cacapon Mountain aquifer and (b) other karst aquifers in the humid east.

- Objective 3. Physical examination of recharge mechanisms during 2007, by measurement of gain and loss rates along mountainside tributaries in the study area.

\subsection{Study Area}

The study area for this investigation consists of the Cacapon Mountain aquifer in Morgan County, located in West Virginia's eastern panhandle (Figure 1). The term “Cacapon Mountain aquifer" (Donovan et al., 2006) refers to the Silurian bedrock aquifer extending between the Tuscarora Formation and the Oriskany Formation, the lower 40\% of which is carbonate rocks. Warm Springs Ridge (Oriskany sandstone) bounds the aquifer on the east and the crest of Cacapon Mountain (Tuscarora quartzite) on the west. The aquifer extends north to the Potomac River, and south to near the intersection of U.S. route 522 with the VA-WV border. Locally this valley is known as Cold Run Valley. 


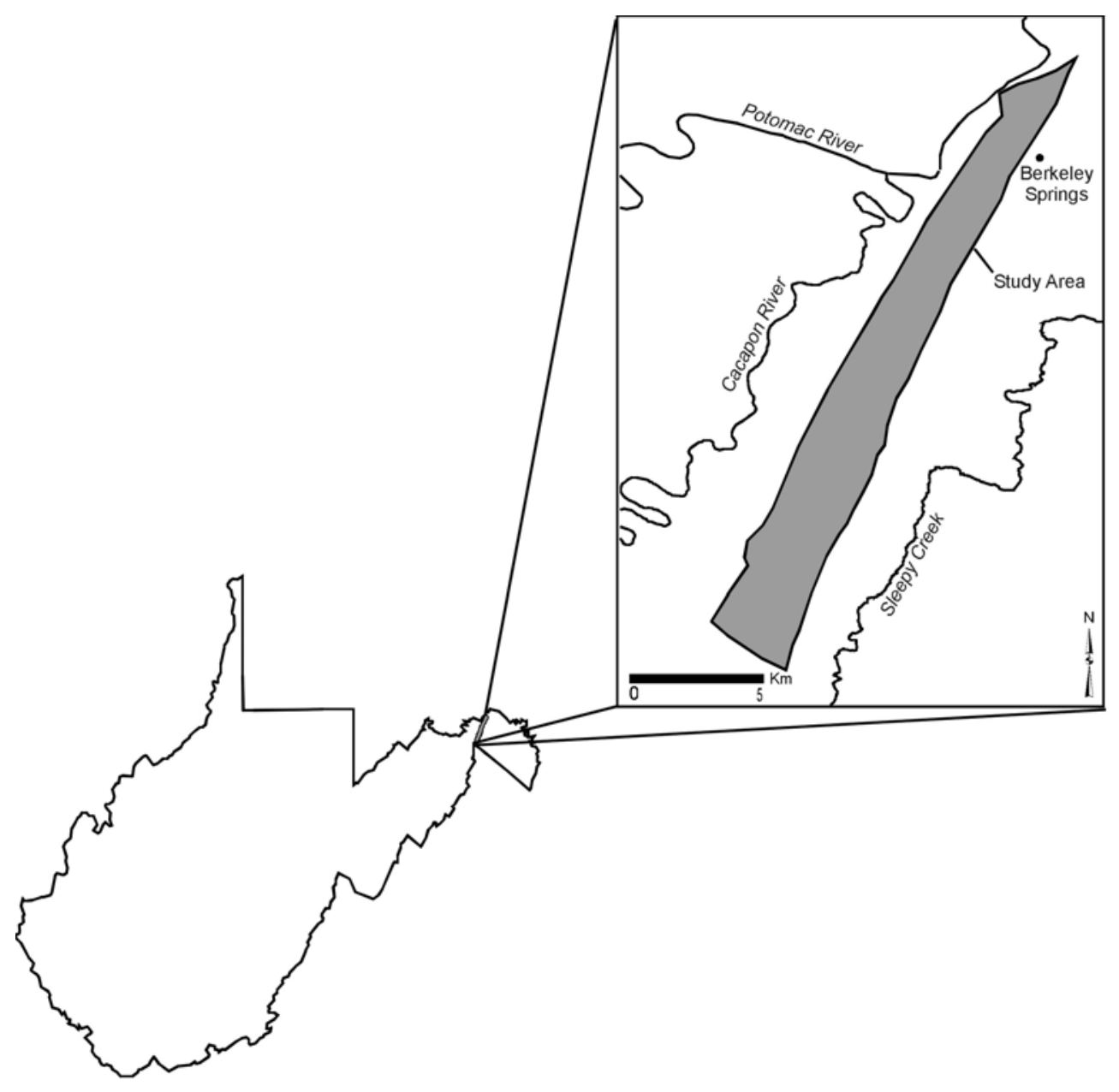

Figure 1. Location map of the Cacapon Mountain aquifer, Morgan County, WV. 


\subsection{Geology}

The study area is located within the Valley and Ridge Physiographic Province, of the Appalachian Highlands. The Valley and Ridge is characterized by a series of parallel ridges underlain by resistant lithologies and lowland valleys underlain by non-resistant lithologies. The structure of the province is dominated by thrust faulting and folding, which largely took place during the Alleghanian Orogeny (Fenneman, 1928). The flow of groundwater within the Valley and Ridge is generally restricted by parallel ridges and is dominantly shallow, with discharge to local streams (Swain, 1991). Ridges and alternating canoe-shaped valleys formed from the erosion along folds of alternating resistant and weak strata (Fenneman, 1928). Although large amounts of water are being withdrawn from aquifers in the Valley and Ridge, recharge processes that dominate here are still poorly understood (Rutledge, 1996).

The structure of Morgan County is dominated by the Cacapon Mountain anticline (Figure 2), the eastern side of which is the focus of this study. The Cacapon Mountain anticlinorium is made up of folded and faulted rocks from Upper Ordovician to Middle Devonian age (Kulander, 1995). The structure formed over a duplex bounded by an imbricate fault ramping upward from the Lower Cambrian, and an upper décollement layer in the Upper Ordovician Martinsburg shale (Kulander, 1995). The anticline is gradually north plunging towards the Potomac (Donovan et al., 2006). From oldest to youngest, the major rock units involved are the Juniata Formation (Ordovician); the Tuscarora Formation, Clinton Group/McKenzie Formation, and Wills Creek / Tonoloway 


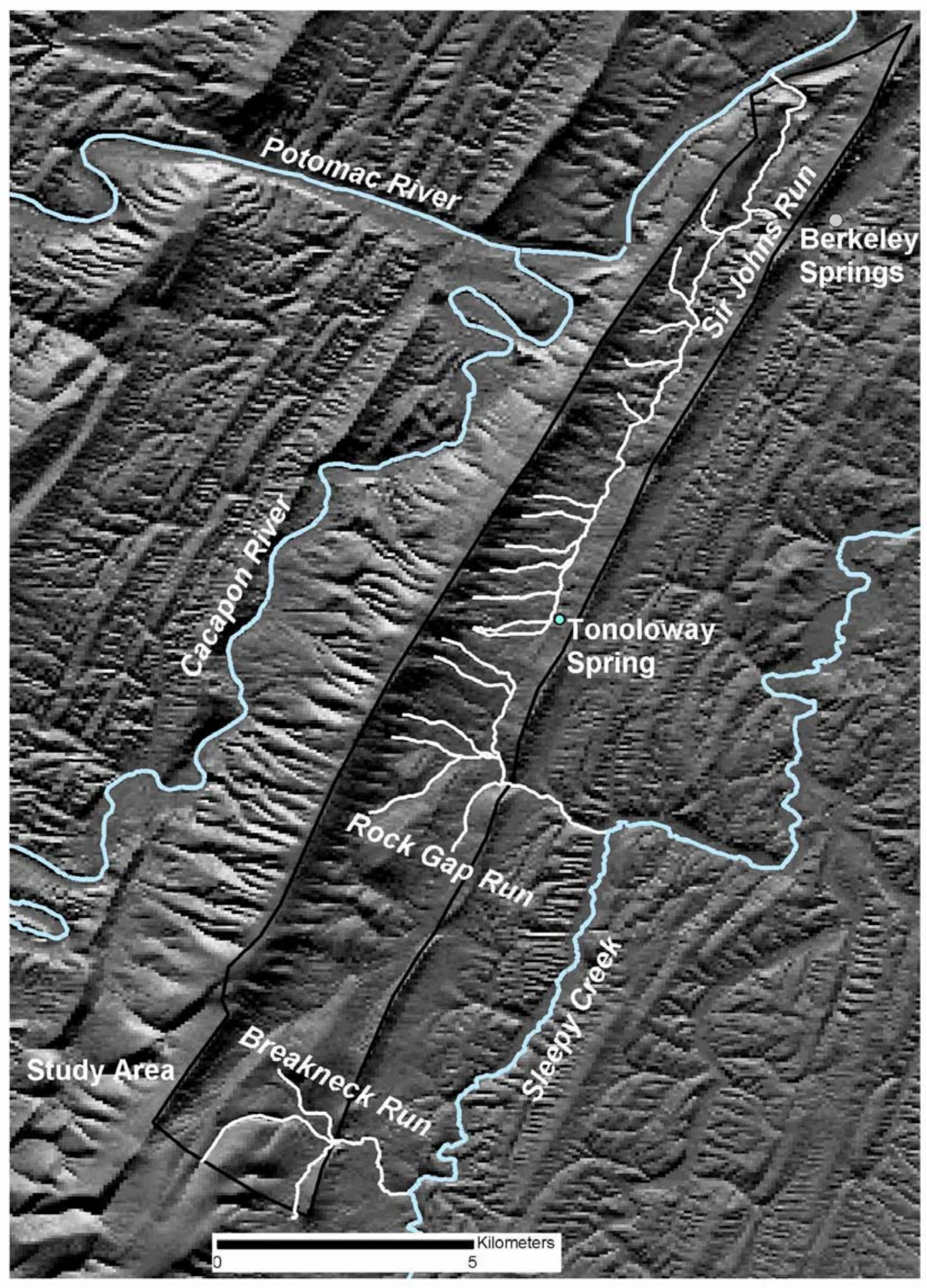

Figure 2. Shaded relief map of Cold Run Valley from the $10 \mathrm{~m}$ digital elevation model (DEM). 
formations, all Silurian; and the Devonian Helderberg and Oriskany formations. The center of the anticline and ridge former of Cacapon Mountain is the Tuscarora Formation. Silurian rocks here include:

- the Tuscarora Formation, 150-250 ft, a white to light gray, resistant marine sandstone, silica cemented, visible cross beds, thin conglomerate layers common, sparsely fossiliferous (Dean, 1995);

- the Clinton Group, 400-450 ft thick, gray and black shales and siltstones, contains a resistant 20-30 foot thick gray or iron stained thinly bedded marine sandstone layer known as the Keefer and a 400-450 ft thick yellow tan and red marine shale, fossiliferous, with sandstone and siltstone layers, known as the Rose Hill Formation (Kulander, 1995);

- the Mackenzie Formation, $175-225 \mathrm{ft}$ thick, a gray to tan calcareous shale interbedded with thin dark blue limestones and calcareous sandstones (Minke, 1964)

- the Wills Creek Formation, 350-450 ft thick, non-fissile gray shale with some redbeds, thin bedded limestone, and a friable, yellow tan sandstone in the top 1015 feet,

- the Tonoloway Formation, 300-400 ft thick, a fine grained, laminated, gray argillaceous marine limestone, some thin shale layers; mud cracks common on bedding surface, fossiliferous (Kulander, 1995).

Devonian age rocks include: 
- the Helderberg Group, 400-450 ft thick, a massively bedded, coarse-grained gray limestone; abundant fossils; dark and light colored chert layers, minor karst development (Kulander, 1995), conduits form parallel to strike,

- the Oriskany Formation, 200-300 ft thick, white to light gray, medium to coarse grained, quartz sandstone with zones of quartz conglomerates, cross beds, abundant marine fossils; both carbonate and silicate cements common (Kulander, 1995)

The Clinton Group and the MacKenzie, Wills Creek, Tonoloway, and Helderberg formations underlie the Cacapon Mountain aquifer (Figure 3). The Helderberg limestone is in most locations the most transmissive rock unit in this sequence due to its tendency to form conduits.

\subsection{Bouldery Colluvial Aquifer}

In the headwaters of both Rock Gap Run and Breakneck Run there are boulder deposits along the flanks of the mountain. These bouldery deposits act as unconfined aquifers that intercept and store infiltration (Figure 4). The sandstone boulders that make up the deposits are primarily sandstones derived from the Tuscarora or Keefer Formations.

\subsection{Previous Investigations}

The Cacapon Mountain aquifer lies within the study area for the Regional Aquifer-System Analysis (RASA) study done by the USGS from 1978-1988 in the Appalachian Valleys and Piedmont (Swain et al., 1991). The analysis gave a sweeping overview of aquifer characteristics in the Valley and Ridge in general, but no specific information describing recharge processes. 


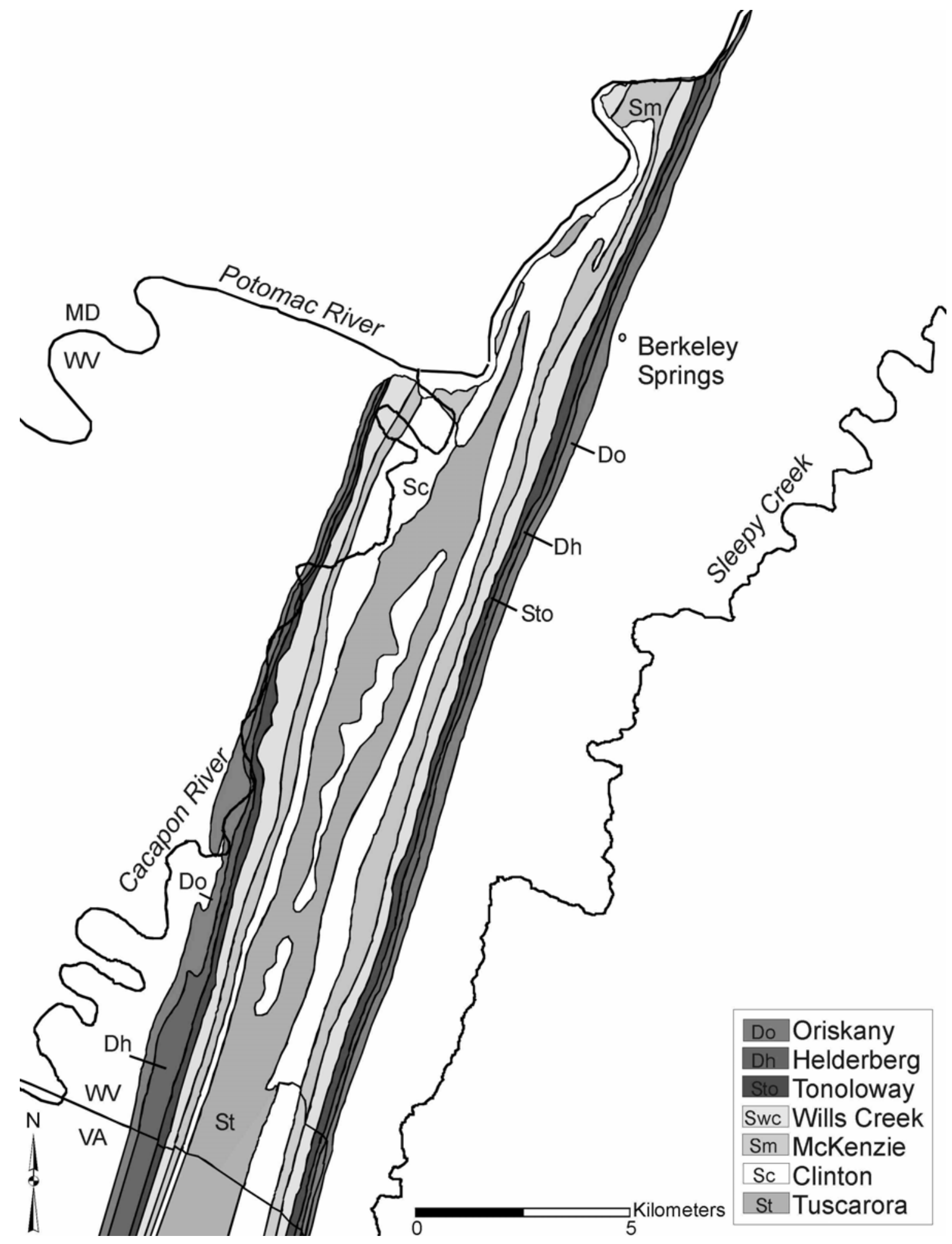

Figure 3. Geology of Cacapon Mountain aquifer after Grimsley (1916). 


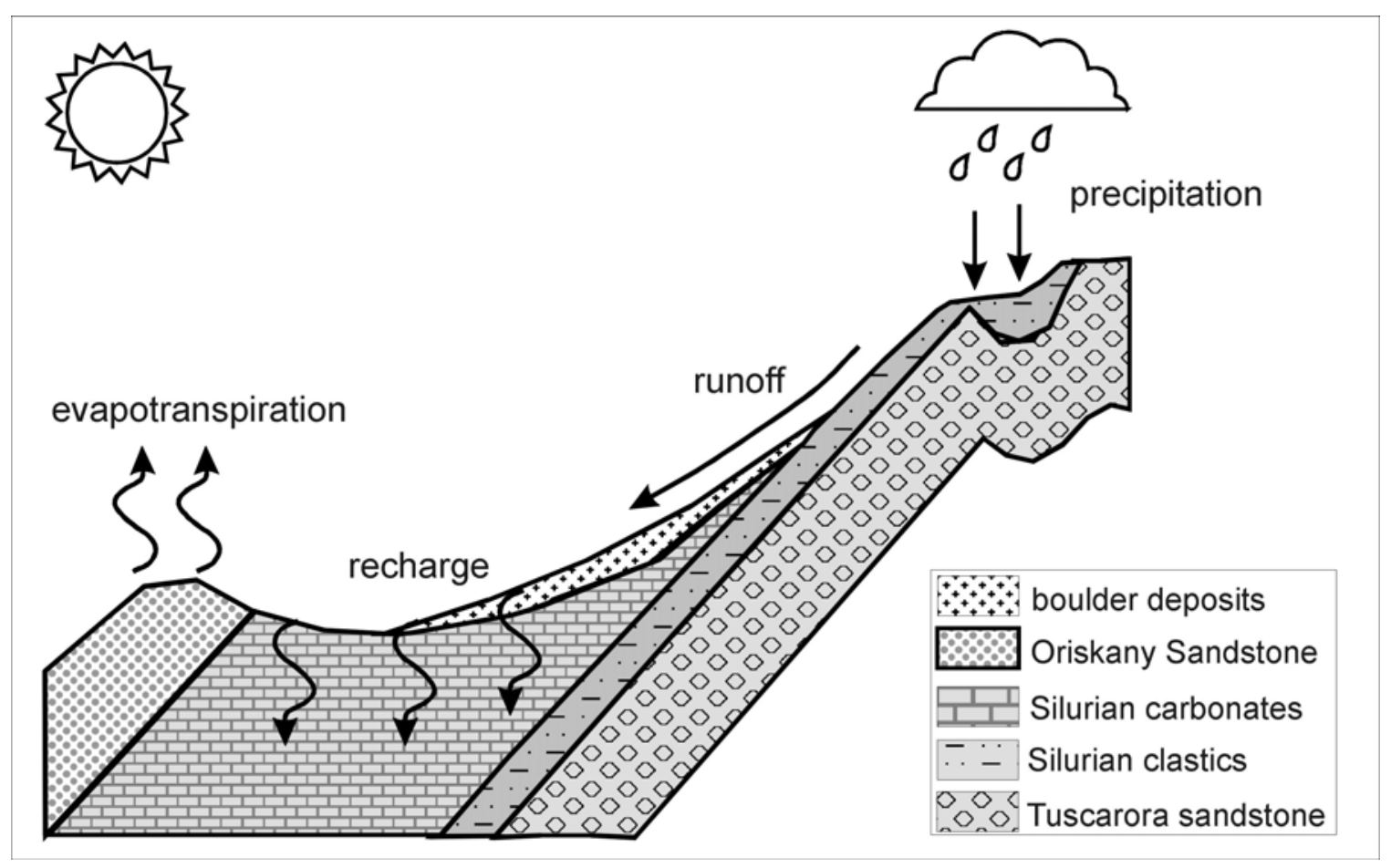

Figure 4. Recharge pathways for Cold Run Valley, after Houston (2002),

Figure 9. 
A geochemical and hydrologic assessment of the eastern side of Cacapon Mountain (Donovan et al., 2006) provided basic hydrogeologic data (well and spring locations, groundwater divides, potentiometric contours) for the Cacapon Mountain aquifer. No data were presented regarding aquifer storage or recharge.

Kozar and Mathis (2001) compiled aquifer characteristics for the state of West Virginia. Reported characteristic included estimates of transmissivity, saturated aquifer thickness, hydraulic conductivity, storage coefficients, specific yield, and recharge rates. Values for stratigraphic units within the Cacapon Mountain aquifer were included in the study. Recharge rates were estimated using long-term average streamflow data, calculated using both RORA (a computer program based on the Rorabaugh method) and other hydrograph separation methods. Recharge estimates were reported for the catchment of the Cacapon River, west of the Cacapon Mountain anticline (Kozar and Mathies, 2001).

Boughton (2006) reported ground-water geochemical data for aquifers of Morgan County, including the Silurian Cacapon Mountain units as well as the overlying Devonian clastic formations. She also described the general hydrogeology of Morgan County (Boughton, 2006).

\section{Elements of hydrograph analysis for recharge estimation}

One of the first to use streamflow hydrographs for estimating recharge was Meyboom (1961), utilizing the water budget relationship that groundwater recharge equals groundwater discharge plus or minus changes in storage. During extended periods with no precipitation, streamflow is maintained solely by groundwater discharge 
(Meyboom, 1961). Time-integrated groundwater discharge during such periods is approximately equal to groundwater recharge.

The Meyboom (1961) method was designed to be useful in areas where there was a good record of streamflow and precipitation but where a detailed hydrogeologic survey would be difficult or uneconomical. The technique is based on the assumption that there is a log-linear relationship between groundwater discharge and time (Rutledge, 1998). If $\log$ of discharge is plotted against time, a straight-line relationship for the individual storm event commonly indicates groundwater recession (Meyboom, 1961). The slope of this straight line with respect to time is the first-order recession constant $\alpha$, first defined by Maillet (1905):

$$
\mathrm{Q}(\mathrm{t})=\mathrm{Q}_{\mathrm{o}} \mathrm{e}^{-\mathrm{\alpha t}}
$$

where $\mathrm{Q}_{0}$ is an initial discharge $\left(\mathrm{L}^{3} / \mathrm{T}\right)$, and $\alpha$ is the recession constant $(1 / \mathrm{T})$. It is best to estimate the recession constant during months when plants are not growing to minimize the impact of transpiration on the observed slope (Rutledge, 1994). Another parameter of interest in analysis of hydrographs is the recession index $\mathrm{K}$ ( $\mathrm{T} / \log$ cycle), equivalent to $\frac{1}{\alpha}$. Based on the value of K, Meyboom (1961) indicated the total potential volume of ground-water discharge over any arbitrary time period V could by calculated as:

$$
\mathrm{V}=\frac{\mathrm{Q} * \mathrm{~K}}{2.3026}
$$

$\mathrm{V}\left(\mathrm{L}^{3}\right)$ is the total volume of baseflow that would drain from the aquifer in an infinite timeframe with no further recharge (Rutledge, 1998). This was expanded upon by Rorabaugh (1964) and Rutledge (1998) to show that the total potential groundwater discharge at a "critical time" after peak flow is equal to about one half of the recharge 
during the peak period interval (Chen, 2003). The "critical time" is estimated by an equation that gives the logarithm of groundwater discharge as a linear function of time (Rutledge, 1998)

Multiple recession slopes are common in many stream hydrographs. According to Meyboom (1961), all stream runoff is composed of three elements; direct runoff, interflow, and baseflow. In karst aquifers, intermediate slopes in the recession have been attributed to "quickflow" (Figure 5). Semi-log plots are commonly used for baseflow separation in the hydrologic literature (Szilagyi, 1999). 


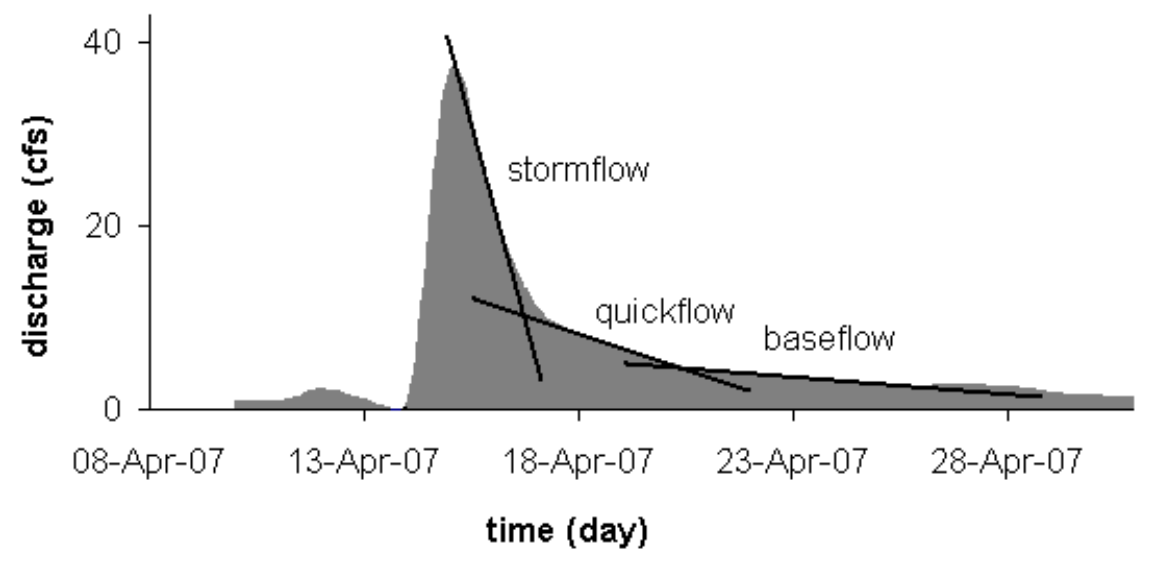

Figure 5. Stream hydrograph from a Mid-April storm event on Rock Gap Run. 


\section{Methodology}

\subsection{A one-year estimate of recharge flux}

In this investigation, three stilling wells were installed to house dataloggers at locations along Rock Gap, Sir Johns, and Breakneck runs (Figure 6). Here, the stilling wells were located in pools with a minimum of large boulders. Wells were fabricated from four-inch diameter Schedule 40 PVC pipe, as shown in Figure 6. The horizontal pipe was installed beneath the creek bed, low enough to remain immersed during low flows. The vertical portion of the stilling well was installed a few feet back from the stream within bank material. An eyebolt was attached about six inches below the casing top of the well and a datalogger was suspended to measure water level.

Dataloggers installed at these three stations continually measured water level in these stilling basins, for translation to discharge using rating curves. Sealed water level loggers (Onset Computer ${ }^{\circledR}$ model U20-001-04 and U20-001-01) were used at all three locations. The loggers measure absolute pressure (reported in pounds per square inch absolute, or psia) and temperature. The time interval between measurements was hourly. A sealed Solinst ${ }^{\circledR}$ BaroLogger, that measures atmospheric pressure variations in feet of water around a zero datum of $13.51 \mathrm{psi}$, was placed at the Ridge logger station in order to correct the loggers for barometric fluctuations. Occasional flow measurements were made using a pygmy-type flow meter and an AquaCalc Pro ${ }^{\circledR}$ data collection unit. During each flow measurement, a minimum of twelve current-velocity measurements was taken across each channel cross section at 0.5 -foot intervals. To develop a rating curve, pressure variations were correlated to flow measurements at each site (Figure 7). 


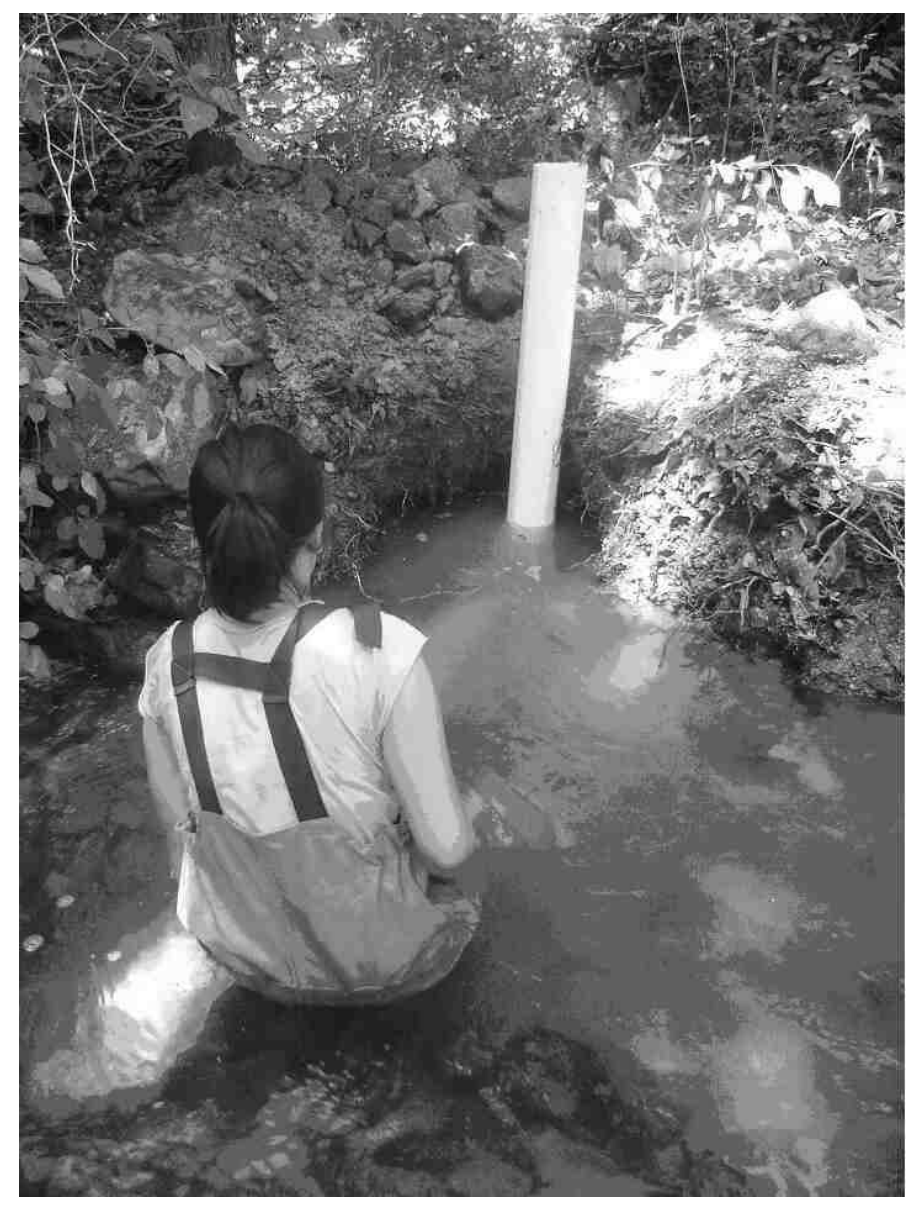

Figure 6. Installing stilling well at Rock Gap Run, July 2006 (photo Matt Finkenbinder). 

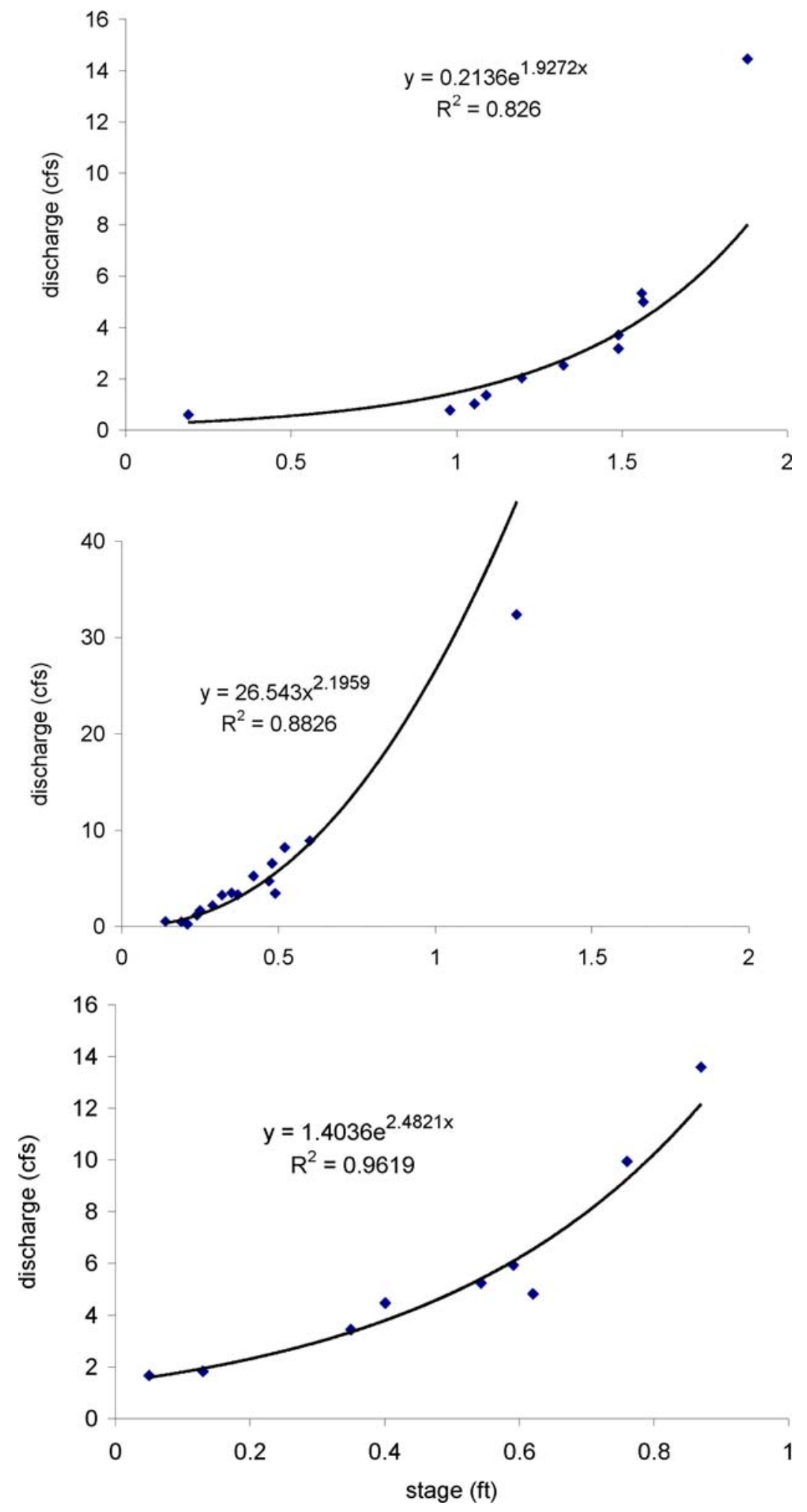

Figure 7. Rating curves for (a) Breakneck Run, (b) Rock Gap Run, and (c) Sir Johns Run. 
Recharge was estimated using three hydrograph separation techniques, two manual methods and one computer model.

The first manual method is a Direct Separation (DS) of each stream's discharge hydrograph. The discharge for a full year was plotted versus time and integrated using the midpoint technique, yielding $\mathrm{V}_{\mathrm{t}}$, the total volume of streamflow for the reference period. The water budget for this flow may be written as:

$$
\mathrm{V}_{\mathrm{t}}=\mathrm{V}_{\mathrm{R}}+\mathrm{V}_{\mathrm{gw}}
$$

where $V_{R}$ is stormflow and $V_{\mathrm{gw}}$ is baseflow, including both slow and quick components. Calculation of recharge requires separation of the storm runoff component from the baseflow component. To accomplish this in the DS method, the following steps were followed:

1. In a plot of log discharge versus time, straight line (i.e., log-linear) segments were fitted to the steepest early slope of the hydrograph, interpreted as storm runoff, and the shallowest recessional slope, considered baseflow,

2. the slopes and intercepts of these two lines were calculated for each storm event,

3. the lines were anti-logged and integrated to estimate (a) the total potential runoff, and (b) the estimated actual runoff, defined as the forwardextrapolated potential stormflow minus the reverse-extrapolated baseflow (Figure 8)

4. the volume of runoff was subtracted from the volume of total flow and normalized to drainage area to give recharge. 


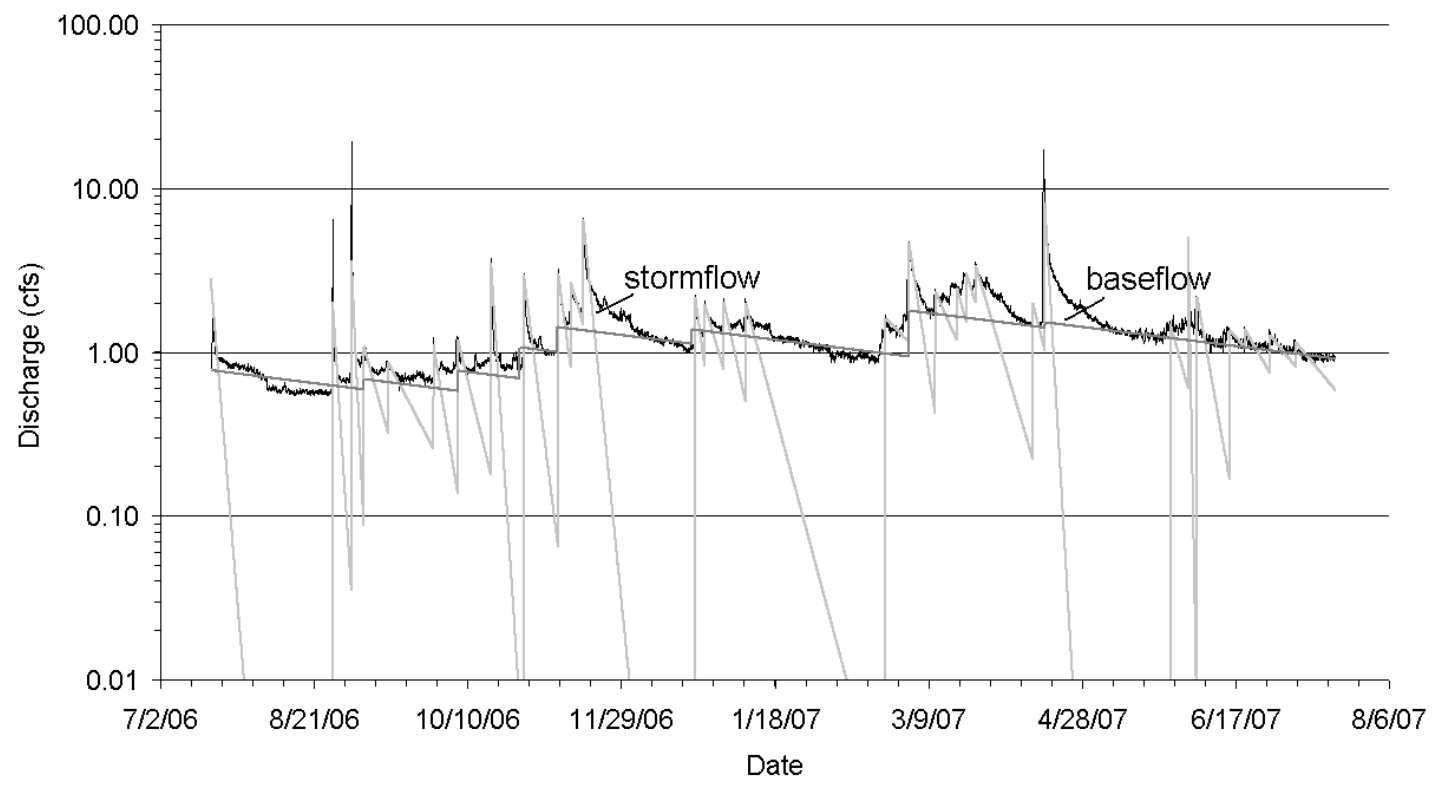

Figure 8. Typical Breakneck Run discharge hydrograph, showing slopes of storm runoff and baseflow components. 
The DS method only excludes runoff from the recharge estimate. Both baseflow and quickflow are included as recharge. The gaging stations on the streams in the study area are all located in the headwaters. Therefore, all stormflow passes the streamflow station within a couple of hours. The hydrographs can, therefore, be relatively easily distinguished into different flow components including quickflow.

The second method was the Recession Curve Displacement (RCD) method, based on the Meyboom (1961) technique. The RCD method uses a summation of the upward shifts in the streamflow recession curve that takes place after recharge events to estimate recharge (Chen, 2003). The method consists of the following six steps (Figure 9;

Rutledge 1998):

1. Determination of the recession index $(\mathrm{K})$ from the hydrograph during a time of little to no recharge, for use in calculation of the critical time after peak flow $\mathrm{T}_{\mathrm{c}}=0.2144 * \mathrm{~K}$,

2. Location of $\mathrm{T}_{\mathrm{c}}$ on the hydrograph,

3. Determination of $\mathrm{Q}_{1}$ (hypothetical groundwater discharge to the stream at $\mathrm{T}_{\mathrm{c}}$ ) based on pre-event recession,

4. Determination of $\mathrm{Q}_{2}$ (hypothetical groundwater discharge to the stream at $\mathrm{T}_{\mathrm{c}}$ ) based on post-event recession,

5. Estimation of recharge for each discrete recharge event $\left(\mathrm{L}^{3}\right)$ as follows:

$$
\mathrm{R}=\frac{2\left(\mathrm{Q}_{2}-\mathrm{Q}_{1}\right) \mathrm{K}}{2.3026}
$$

The final method used was direct calculation using RORA (Rutledge, 1998). This method minimizes subjectivity in separating baseflow during long periods of multiple 


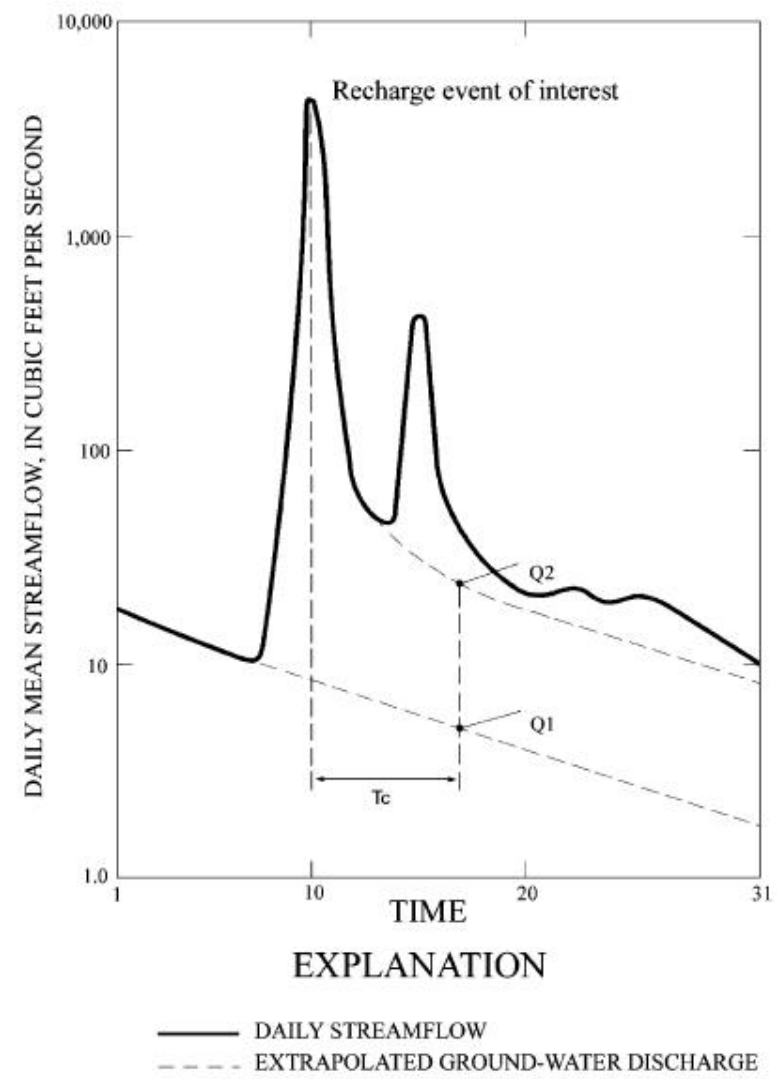

Figure 9. Calculating recharge using the recession curve displacement method, after Rutledge (1993). 
frequent precipitation events, when visual separation is difficult (Kozar and Mathes, 2001).

All streamflow-based methods for estimating recharge implicitly assume that groundwater recharge is equal to streamflow; in reality, it is possible for several other sources of groundwater discharge (i.e., evapotranspiration, abstraction, and underflow) that are all part of recharge to go unmeasured in those techniques (Rutledge, 1996). Underflow could be occurring beneath the aquifer of this study because of its karst nature. Underflow may be occurring as deep artesian flow through the Helderberg to locations outside of Cold Run Valley. The chemical signature of Ladies Spring, a thermal spring at Berkeley Springs on the east side of Warm Spring Ridge, is identical to that of springs in the Helderberg formation in Cold Run Valley (Donovan et al., 2006). The similarities in spring chemistry suggest that the recharge area for Ladies Spring could lie within Cold Run Valley. In order for recharge from Cold Run Valley to reach Ladies Spring on the opposite side of Warm Spring Ridge, underflow would be a prerequisite.

Seepage runs were done on Rock Gap to note any significant gains or losses but no quantification of the volume of underflow will be done. The recharge estimations may be low if losses are occurring upstream of the measuring point.

During 2006-2007, Rock Gap Run was intermittent. Therefore, the Rock Gap Run data were cropped at $0.25 \mathrm{cfs}$ (the smallest flow measurable with a flow meter on Rock Gap Run) to allow discharges to be plotted on a logarithmic scale (Figure 10). 


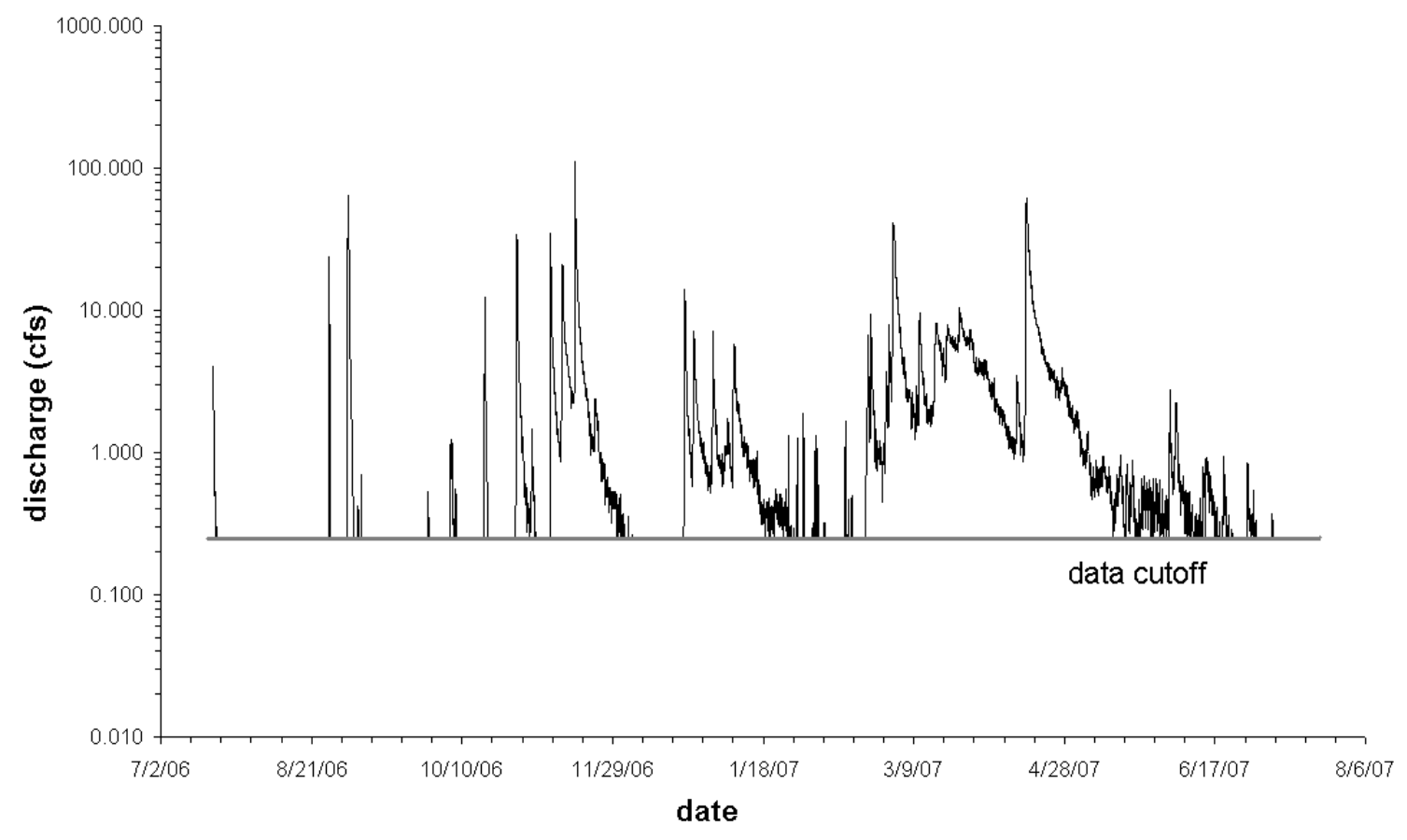

Figure 10. Rock Gap Run was cropped at $0.25 \mathrm{cfs}$, the detection limit of the flow meter. 
Streamflow data show daily fluctuations at the Breakneck Run station due to diversion from the stilling basin to a West Virginia Division of Natural Resources (WVDNR) Fish Hatchery downstream. Diversion occurs at all seasons, but only during low flow is nearly all of the streamflow diverted. To correct these data for gaps due to disturbance of pool levels at the weir, Breakneck Run flow during periods of flow diversion was correlated to those at Rock Gap Run to smooth out these fluctuations due to the streamflow diversion (Figure 11). Plotting the discharge of Rock Gap Run versus Breakneck Run yielded a $\mathrm{R}^{2}$ value of 0.91 , suggesting a strong correlation.

\subsection{Analysis of recharge rate variations}

\subsection{Cacapon Mountain aquifer}

The data collected from the three streamflow stations were compared to each other to explain differences in discharge, recession constants, and hydrograph characteristics. Differences were based on size and geologic characteristics of each drainage area. The assumption was made that topographic divides correspond to groundwater divides. The drainage areas of streams were delineated in ArcGIS 9.2, using 10-meter digital elevation models (DEMs). Spatial variations in climate were examined by comparing precipitation data from the rain gages at Cacapon State Park; Winchester, VA; Hancock, MD; and at Falling Waters, WV.

\subsection{Montane and lowland karst (humid east)}

The data collected from the Cacapon Mountain aquifer were also compared to existing data in a carbonate aquifer of similar settings and in a lowland setting. Flow data were obtained from the USGS National Water Information System database for Back Creek near Jones, WV (\# 01614000), Cacapon River near Great Cacapon, WV 


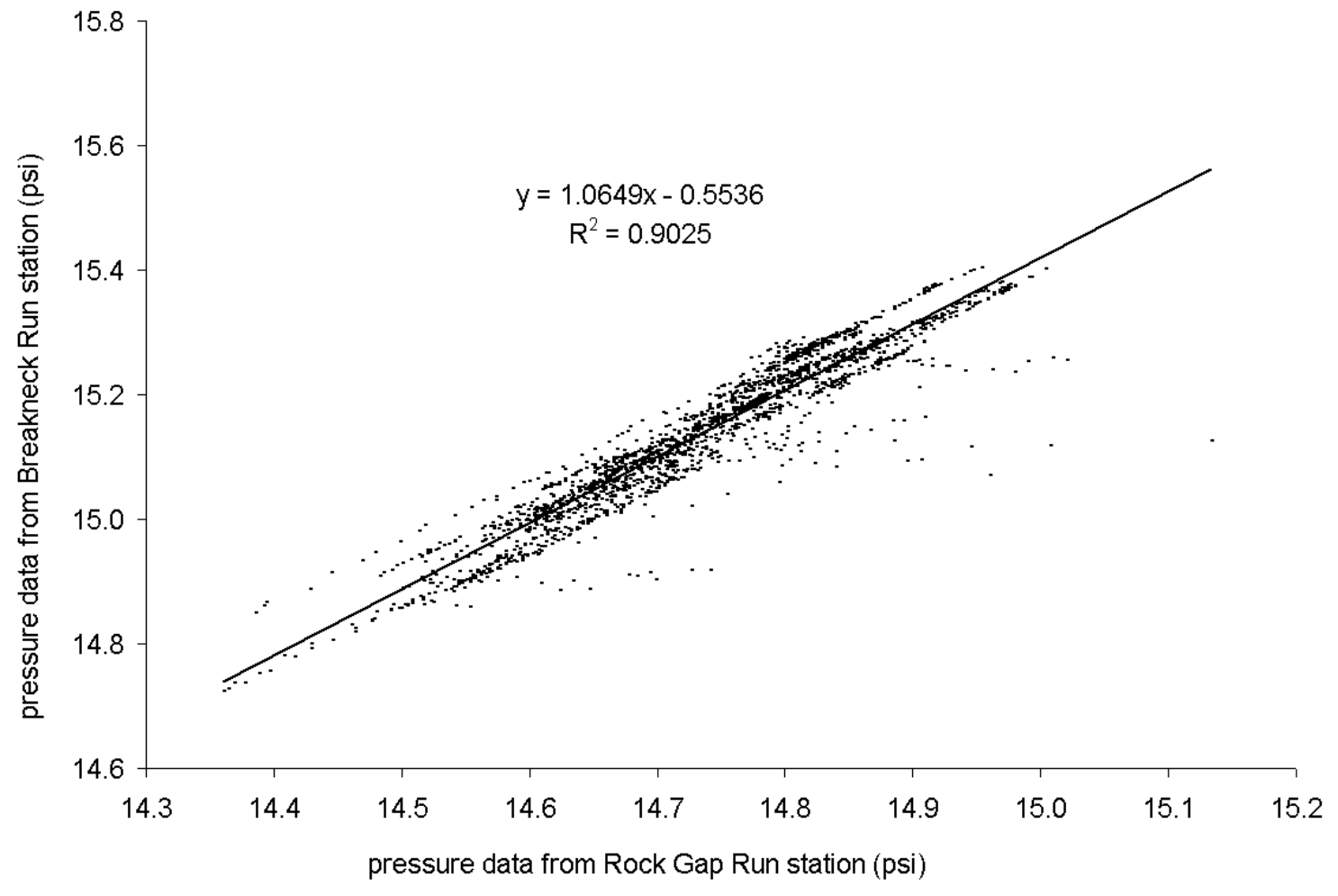

Figure 11. Raw total pressure data for Rock Gap Run and Breakneck Run from July 2006-July 2007. 
(\#01611500), and Patterson Creek near Headsville, WV (\#01604500) (Figure 12). The data employed were daily average discharge from July 2006-July 2007. The discharge data from these sites were used to estimate recharge using the same methodology as the streams in the aquifer.

\subsection{Physical examination of recharge mechanisms}

The most important recharge period for the Cacapon Mountain aquifer is in late winter and early spring, as in most humid temperate climates. Two types of seepage runs were performed on Rock Gap Run in early spring when snowmelt was at a maximum. The first seepage run on 4/15/07 involved two operators measuring flow along one of the major tributaries of Rock Gap Run over approximate 150-meter intervals. The second type of seepage run was done on $4 / 25 / 07$ and $4 / 27 / 07$. These runs involved a reconnaissance team walking the recharge area during a snowmelt event and marking locations, either visually or based on flow measurements, where water is lost to the subsurface. Starting at the base of the mountain working downstream sampling was done at 150-meter intervals. All locations where flows emerged, intersected, or submerged were marked with a Garmin GPS. Both types of survey were done with a pygmy style flow meter and an AquaCalc Pro data collection unit. Instrumentation accuracy on the AquaCalc Pro is $0.005 \%$. Replicating flow measurements assessed user error; the standard deviation was 0.097 . Identifying areas where water is entering or exiting the ground gives a better understanding of recharge mechanisms. 


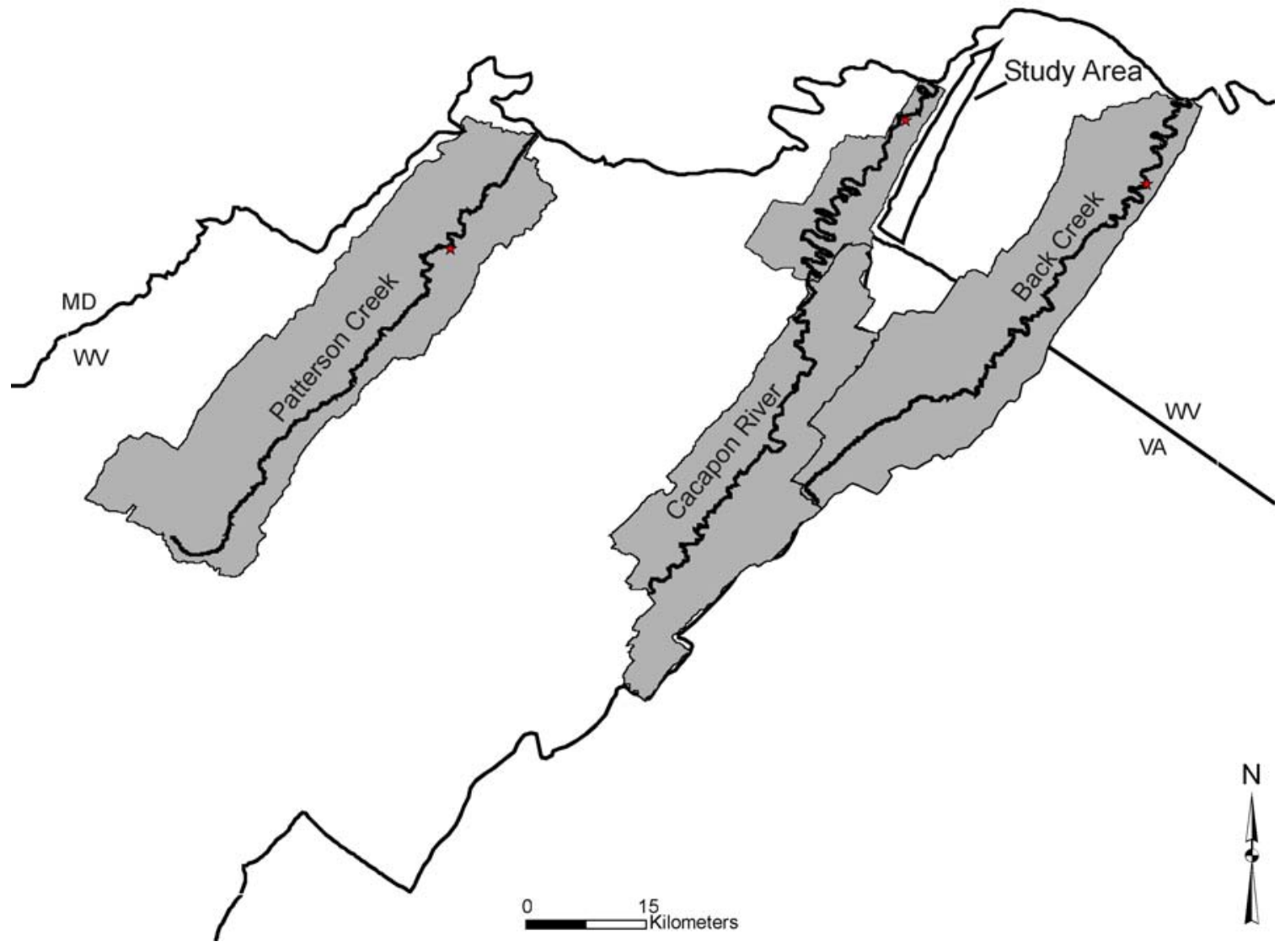

Figure 12. Streams catchments for which recharge rates were calculated in this study, Eastern Panhandle, WV. USGS gageing stations denoted with red stars. 


\section{Results}

\subsection{Hydrograph Analysis}

\section{$\underline{4.12 \text { Multiple Recession Slopes }}$}

The hydrographs of karst streams traversing Cacapon Mountain aquifer have three distinct recession slopes, representing storm runoff, interflow and/or quickflow, and baseflow, from early to late time. Interflow represents infiltration and lateral flow through the subsurface to the channel that reports to the stream more slowly than surface runoff but more quickly than baseflow (Ramirez, 2000). Quickflow, a term applied exclusively to karst aquifers, refers to flow through a network of high velocity subsurface drains (Padilla, 1994). Due to similar speed of their flow regimes, it is difficult to separate quickflow from baseflow and stormflow in a hydrograph with complete confidence. Additionally, each method of baseflow separation has, depending on the nature of the hydrograph, potentially considerable subjectivity (Szilagyi, 1999).

Stream and spring hydrographs both display quickflow and baseflow, but only stream hydrographs display runoff. Tonoloway Spring (Figure 13) is located in the headwaters of the Sir Johns Run watershed, roughly 2.4 kilometers from the streamflow station on Rock Gap Run. In Figure 14, Tonoloway Spring and Rock Gap Run flow hydrographs are plotted semi-logarithmically against time for a storm event in mid-April 2007, chosen because it shows evident recession following a single intense rainfall event. The springflow data were rescaled to align baseflows of the two hydrographs. Both hydrographs display quickflow (the lines of intermediate slope in Figure 14) 


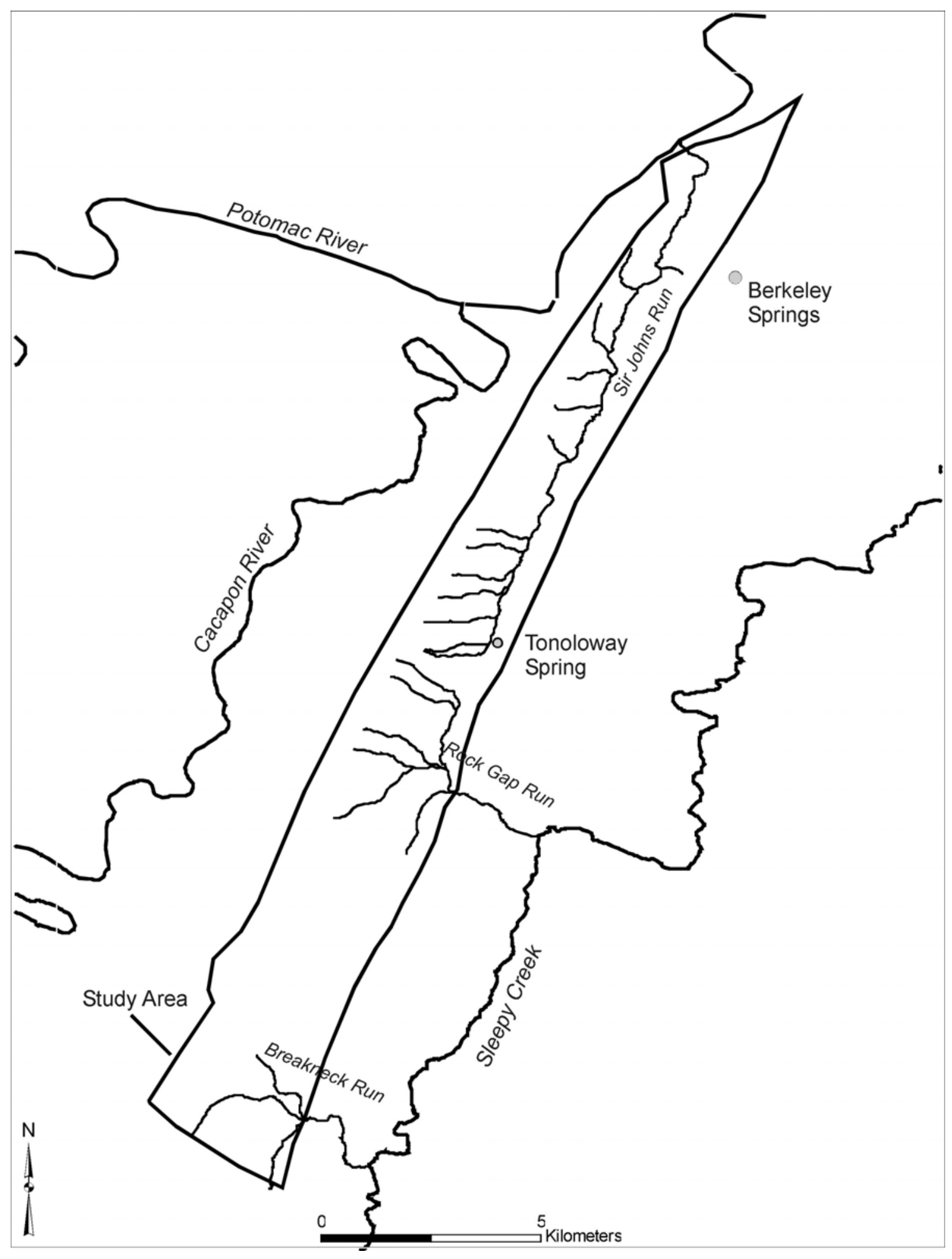

Figure 13. Location of Tonoloway Spring in the Cacapon Mountain Aquifer. 


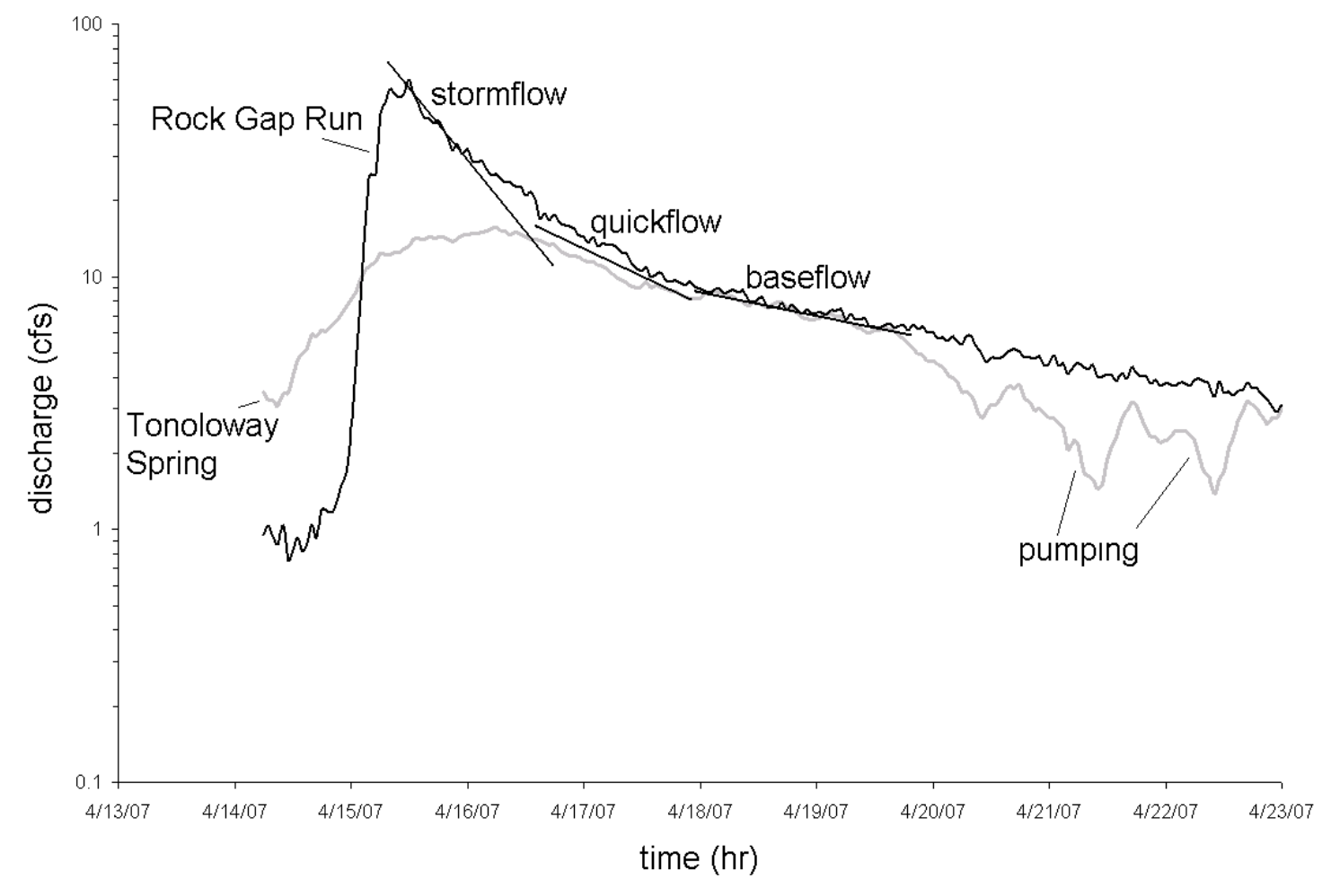

Figure 14. Hydrographs from Rock Gap Run and Tonoloway Spring, showing three distinct recession segments. 
and baseflow components but only the stream hydrograph displays a runoff component. This figure is interpreted to show the unit hydrograph for Rock Gap Run (as well as Tonoloway Spring) and the approximate partition between baseflow and quickflow.

Tonoloway Spring flow data is useful for breaking down the quickflow in comparison to Rock Gap Run because of runoff overlapping with quickflow, in this as well as other events. These quickflow slopes can be used to separate out stormflow during multiple recharge events where visual separation is difficult.

Using this approach to distinguish between the three flow components, the hydrographs of each stream in the study were separated. The earliest hydrograph portion after the onset of precipitation, up to and including the steep stormflow recession, was interpreted as storm runoff. In some cases, this storm recession was log-linear, but its slope varied from event to event. Similarly, the late log-linear slope was interpreted as baseflow; baseflow slope was generally uniform from event to event at individual stations. The intermediate streamflow between storm runoff and baseflow was interpreted as "quickflow" and had a slope intermediate between these two. The percentage of total flow in each of these three components was estimated by integration using the DS method (Figures 15-17).

\subsection{Recharge rate for Cacapon Mountain Aquifer}

\section{$\underline{4.21 \text { Variations between Cacapon Mountain drainages }}$}

Table 1 shows variation in interpreted stormflow, quickflow, and baseflow for the three Cacapon Mountain stations. Each of the three watersheds displayed different proportions of these components. Sir Johns Run and Breakneck Run are both dominantly 


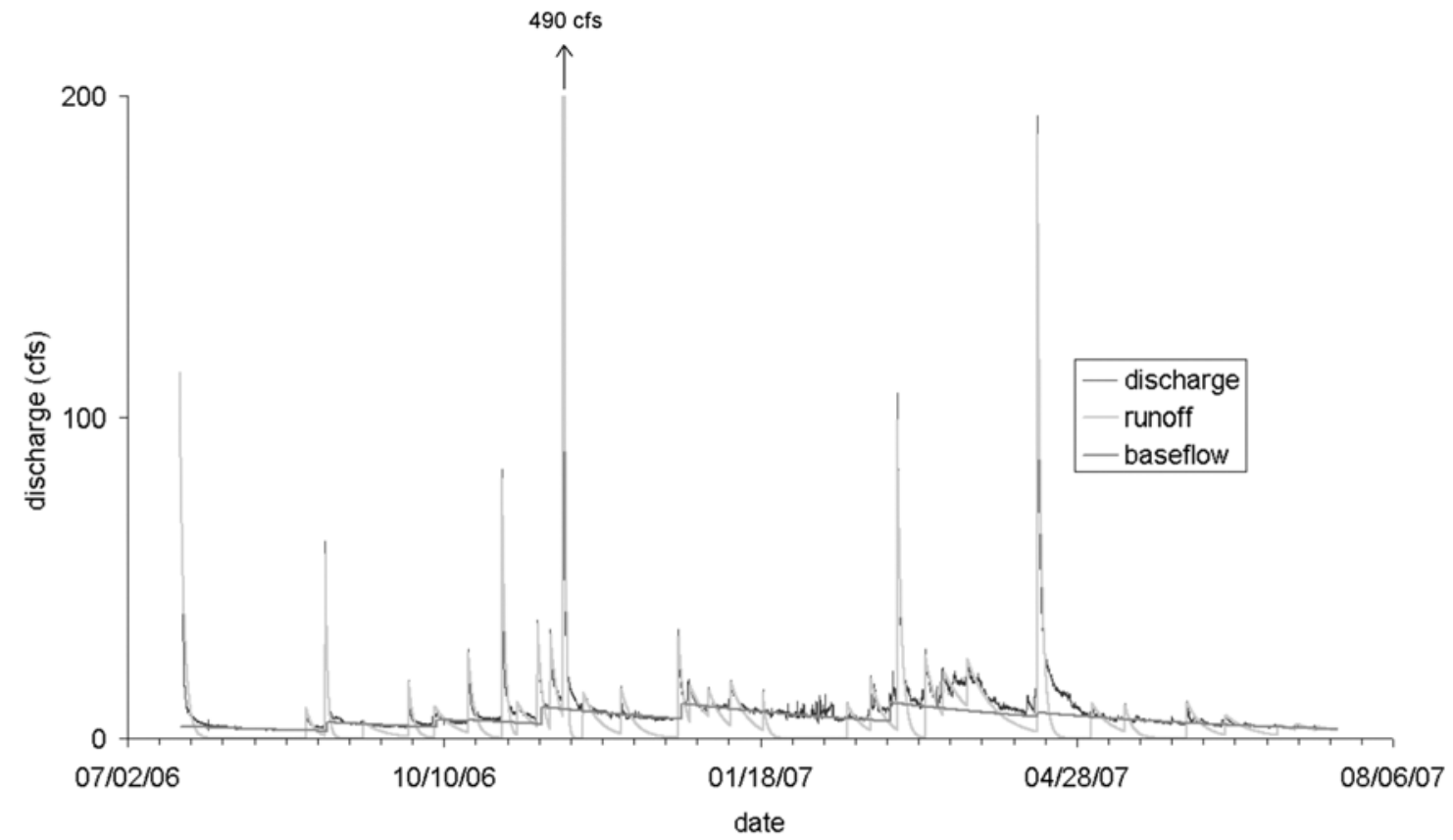

Figure 15. Base flow separation, Sir Johns Run. 


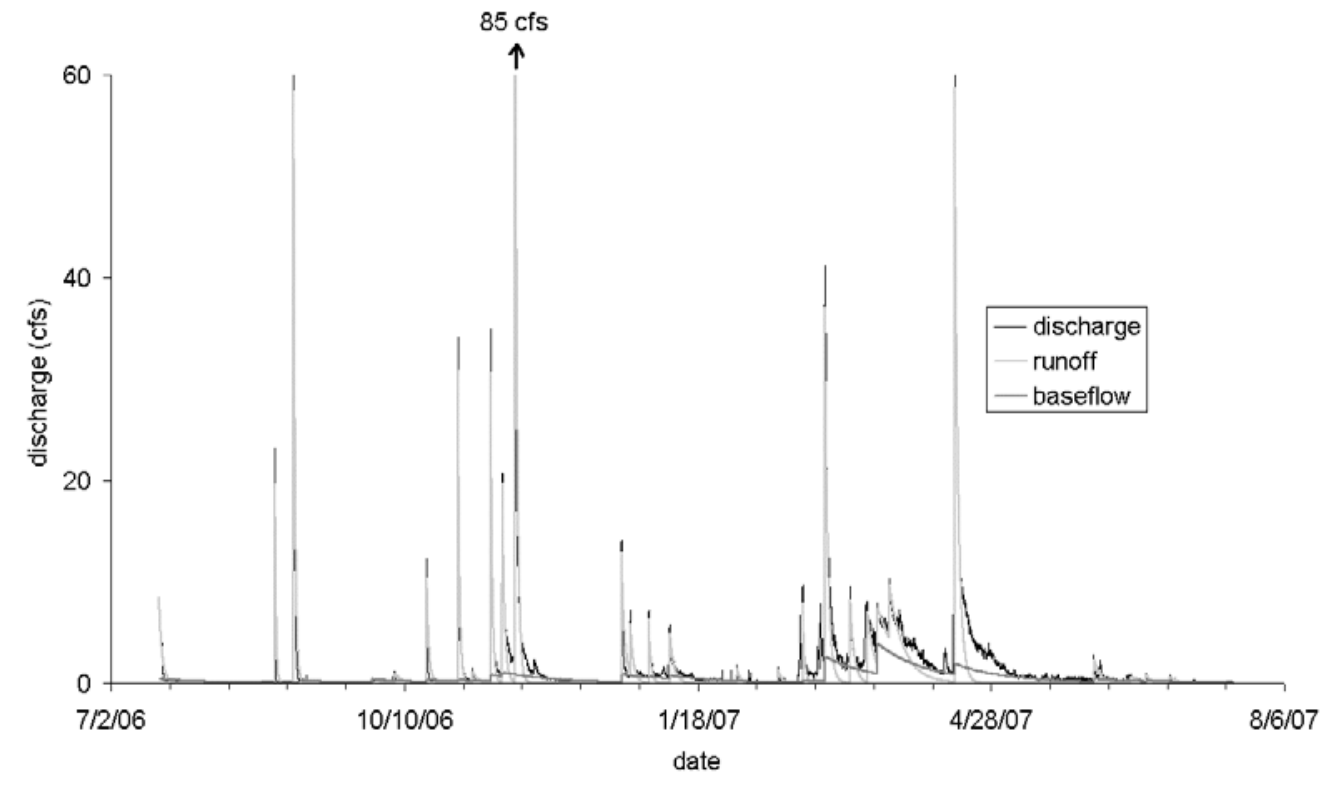

Figure 16. Base flow separation, Rock Gap Run. 


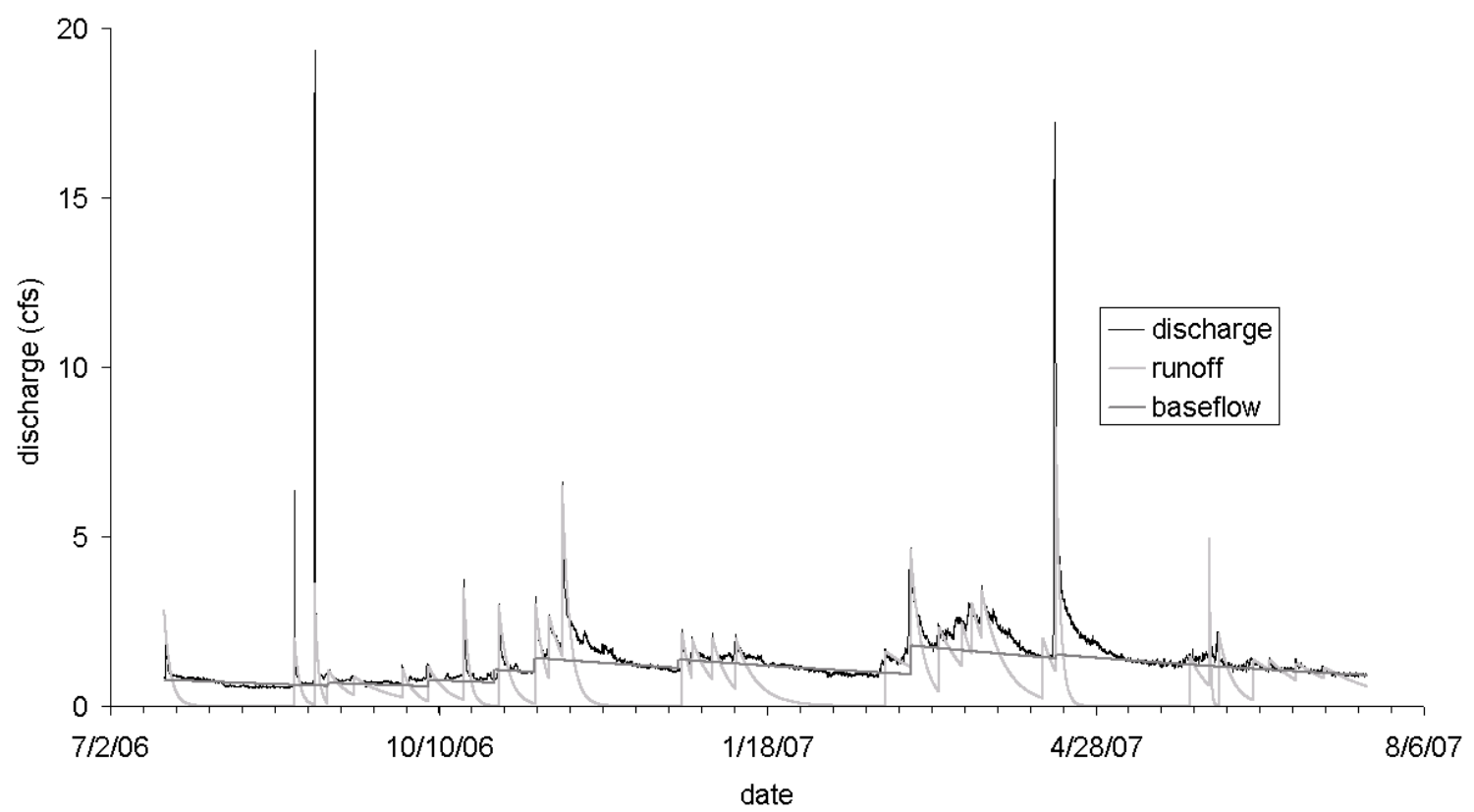

Figure 17. Base flow separation, Breakneck Run. 
Table 1. Flow components for the streams in Cold Run Valley.

\begin{tabular}{cccc}
\hline & Sir Johns Run & Breakneck Run & Rock Gap Run \\
\hline Total Flow (in) & 18.51 & 7.36 & 5.60 \\
Total Baseflow (in) & 9.85 & 5.81 & 1.63 \\
Total Runoff (in) & 5.21 & 0.79 & 3.08 \\
Total Quickflow (in) & 3.46 & 0.76 & 0.89 \\
\hline
\end{tabular}


baseflow (51\% and 77\%, respectively). Rock Gap Run, on the other hand, is runoffdominated (55\%). Quickflow was a minor component in all three streams.

\subsection{Differences between baseflow-separation methods:}

Estimates of the recharge rates by different techniques at each watershed are shown in Table 2 for Direct Separation (DS), Meyboom (MB), Recession Curve Displacement (RCD) and RORA. These methods differ in (a) which flow components are included in the recharge estimates and (b) the techniques used to resolve components.

Recharge estimates are lowest (Table 2) for the MB and RCD methods, neither of which incorporates quickflow into recharge. The DS method, which includes quickflow, gives higher recharge estimates. The magnitude of difference between the MB-RCD and DS estimates appears related to the magnitude of quickflow at each station. RORA, which is a numerical implementation of the RCD method, yielded the highest recharge estimates for all streams.

\subsection{Spatial variations in recharge rates within the Cacapon Mountain Aquifer}

Daily precipitation accumulations between July 2006 and July 2007 from Cacapon State Park were plotted against precipitation from several surrounding weather stations: Winchester, VA, Hancock, MD, and at Falling Waters, WV. This was done to check for spatial variation in the precipitation on Cacapon Mountain (Figure 18). These data indicate that there was insignificant spatial variation in precipitation over this time period.

Geological differences between the watersheds in Cold Run Valley are minor. All the units from the Tuscarora up-section to the Helderberg/Oriskany underlie all three catchments. There is, however, some difference in the orientation and position of the 
Table 2. Estimated recharge rates for 2006-07 water year.

\begin{tabular}{ccccccc}
\hline Total Recharge (in) & \multicolumn{5}{c}{ Sir Johns Run } & Breakneck Run \\
\hline NI(in) & 13.31 & 6.57 & 2.52 & 10.29 & 6.17 & 7.05 \\
RCD (in) & 8.66 & 5.44 & 1.77 & 8.78 & 7.39 & 10.35 \\
RORA(in) & 13.16 & 7.52 & 3.67 & 11.34 & 9.18 & 8.35 \\
Meyboom (in) & 9.86 & 5.82 & 1.63 & 7.21 & 5.50 & 3.84 \\
\hline
\end{tabular}




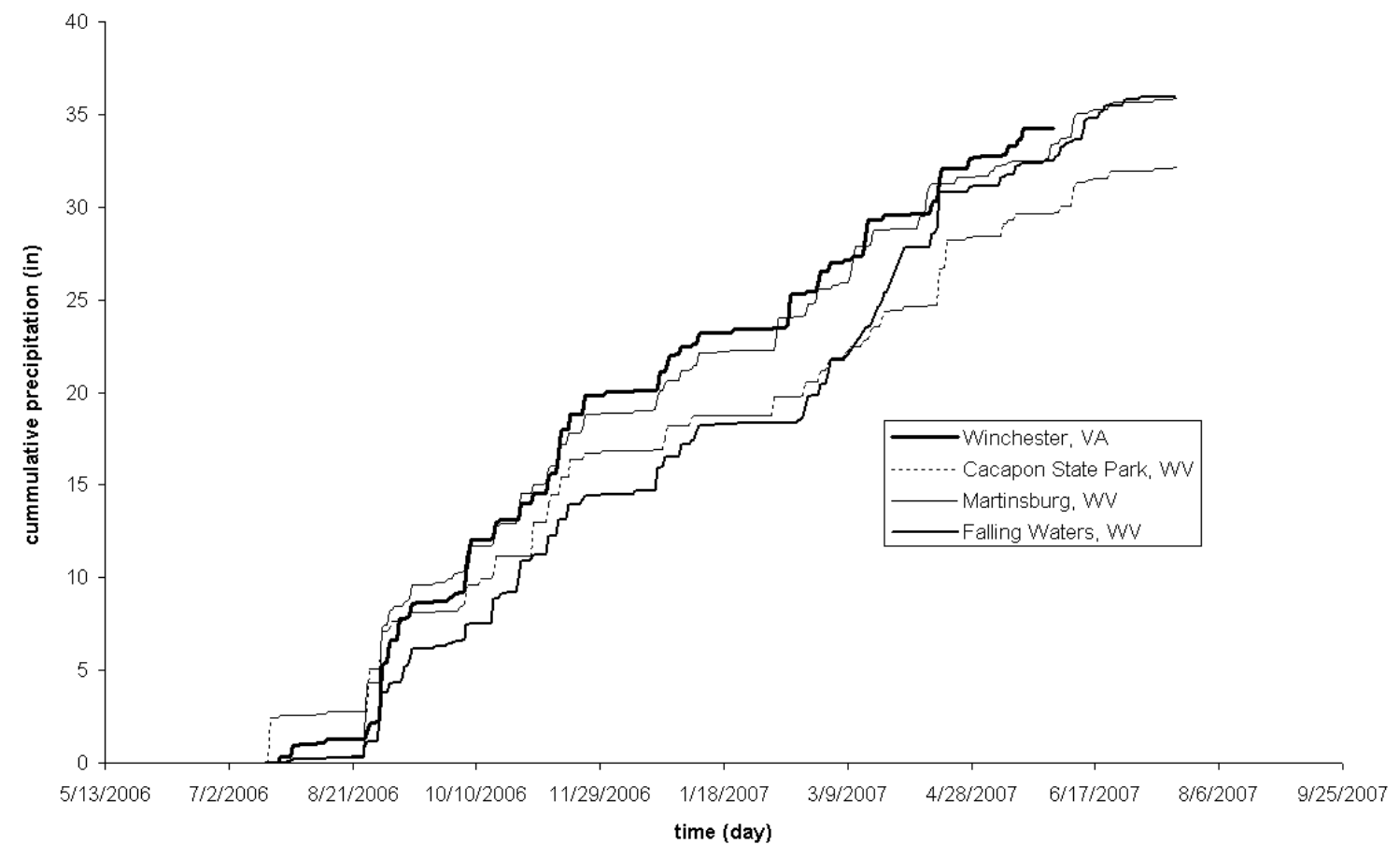

Figure 18. Cumulative precipitation versus time for Cacapon State Park and the surrounding areas. 
streams themselves, as opposed to their catchments. Sir Johns Run flows parallel to strike only and flows primarily over the middle Silurian Tonoloway, Wills Creek, and Clinton-Mackenzie formations. It does not cross the conduit-forming Helderberg limestone. On the other hand, Rock Gap Run and Breakneck Run are strike-normal and cross the Helderberg flowing perpendicular to strike.

\subsection{Comparison of recharge rates to other regional aquifers}

All watersheds chosen for comparison are located in the eastern panhandle of West Virginia, in similar geologic /topographic settings. The same methods (DS, RCD, RORA) used for recharge estimates in Cold Run Valley were used with the comparison streams; results are shown in Table 2. Cacapon River watershed (Figure 12) is much larger and higher in flow than any of the watersheds in Cold Run Valley. Despite being of higher stream order, this watershed was selected because it is located on the western flank of Cacapon Mountain and drains some areas of similar geology to Cold Run valley, although clastic rocks dominate its watershed.

Patterson Creek watershed (Figure 12) is underlain largely by the Brallier and Harrell shales (Devonian). Nonetheless, the setting is structurally similar to Cacapon Mountain. It also, however, drains Knobley Mountain, similar to Cacapon Mountain, an anticline exposing Silurian rocks at its core. The stream valley lies between Knobley and Patterson Creek mountains.

Back Creek watershed (Figure 12) includes North Mountain, to the east of the creek, and Sleepy Creek Mountain, to its west. North Mountain is a thrust fault with Tuscarora sandstone along its footwall near the crest of the mountain. Along the western 
flank of the mountain toward Back Creek, the geology is very similar to Cold Run Valley although Back Creek is synclinal and flows mainly over Mahantango shale (Devonian).

In agreement with the streams in Cold Run Valley, the MB methods gave lowest recharge estimates. However, in contrast to the Cacapon Mountain results, the RCD-MB estimates were not lower than the DS estimate. This may be a result of the minor role of quickflow in these other streams.

\subsection{Water Budget}

A simple water budget was calculated for Sir Johns Run. The total measured precipitation between July 2006 and July 2007 at Cacapon State Park was 32.10 inches. The average annual precipitation, averaged between 1961-1990, is between 36 and 40 inches (Spatial Climate Analysis Service, 2000). According to the DS method, total runoff (stormflow) in the Sir Johns run watershed was 5.4 inches and total recharge was 13.04 inches. Applying a water budget to these values:

$$
\text { P-R-Q } \text { runoff }-E T-U=0
$$

where $\mathrm{P}$ is precipitation, $\mathrm{R}$ is recharge, $\mathrm{Q}$ is runoff, $\mathrm{ET}$ is evapotranspiration, and $\mathrm{U}$ is utilization (abstraction). Assuming zero storage change in aquifers, this estimates 13.66 inches/year lost to evapotranspiration and abstraction. The average evapotranspiration for the eastern panhandle of West Virginia is 15-25 inches/year (Hanson, 1990). These results are credible; as ET should diminish in periods of lower than average flows.

\subsection{Recharge Mechanisms of the Aquifer}

\section{$\underline{4.61 \text { Hydrogeology of Cold Run Valley }}$}

The hydrology and hydrogeology of the three drainages in Cold Run Valley are all distinct (Plate 1). Coarse colluvium dominates the watersheds at both Breakneck and 
Rock Gap Run. Sporadic sinks and springs occur across the boulder fields and subsurface flow can be heard while walking the area. Both watersheds have known sinks, associated with Helderberg conduits, that discharge during intense storm events (Plate 1). The conduit diameter in the Rock Gap Run watershed is large enough to transmit golf balls from an up gradient golf course.

Structure and geomorphology play an important role in the groundwater flow paths and flow patterns within Cold Run Valley. During baseflow, the streams in Cold Run Valley are completely groundwater-fed. Two categories of springs are present in the recharge area, based on elevation (Plate 1). First, at higher elevation, springs discharge from clastic rocks along the high flanks of Cacapon Mountain. Second, springs at lower elevations discharge from colluvial deposits, clastic rocks, or limestone.

The high-elevation springs are associated with a series of strike-normal fractures spacing at approximately 250-300 meter intervals (Figure 19). The fractures can be seen both on the aerial photos and in the 10-meter digital elevation models (Figure 20). The high spring elevations are evidence that recharge is occurring on or around the crest of the mountain. These springs infiltrate into colluvial deposits that blanket the eastern flank of Cacapon Mountain and slowly drain the water either to the stream or underflow. These deposits retain this groundwater sufficiently long that baseflow drains into these 


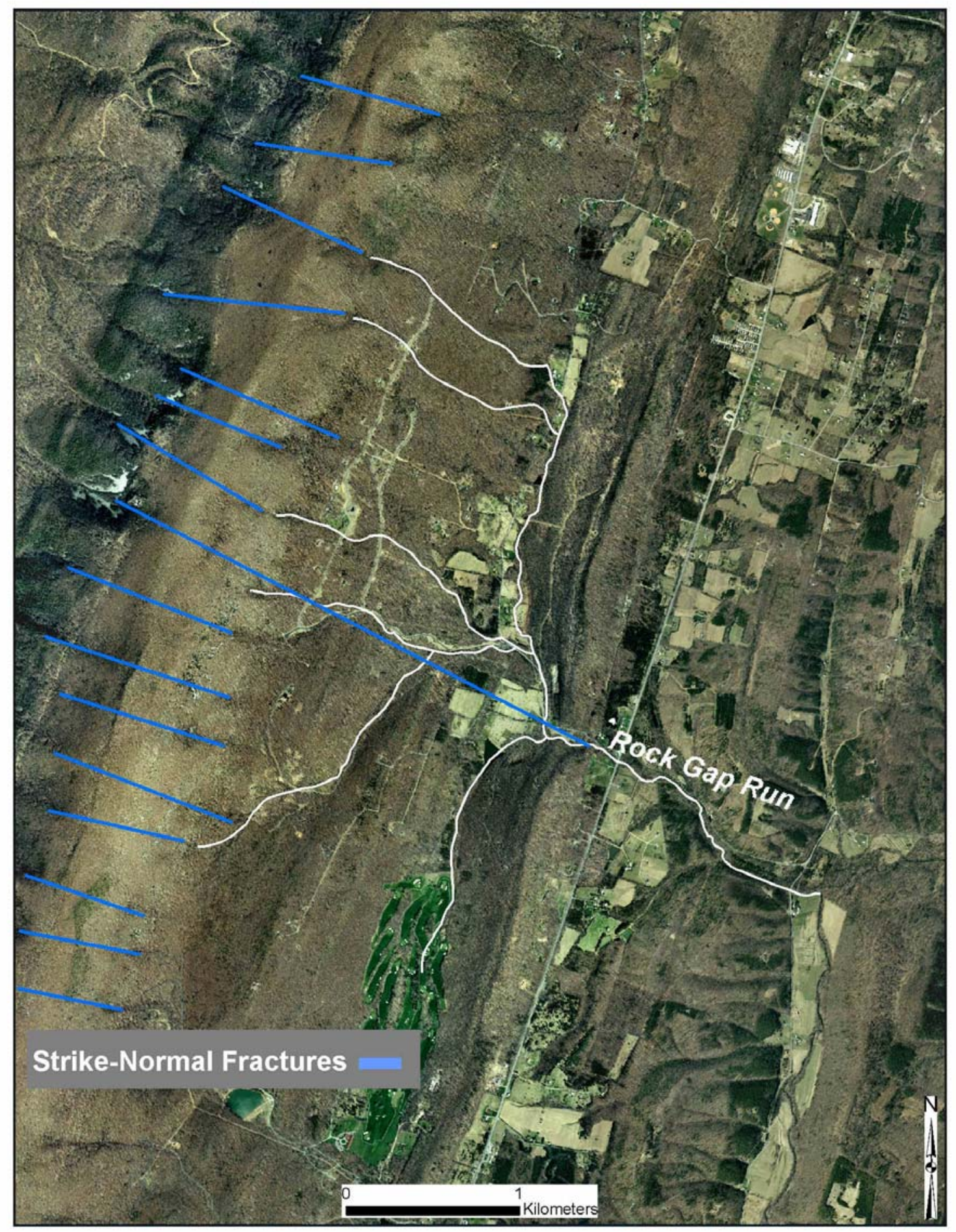

Figure 19. Lineament spacing in the Rock Gap Run watershed 


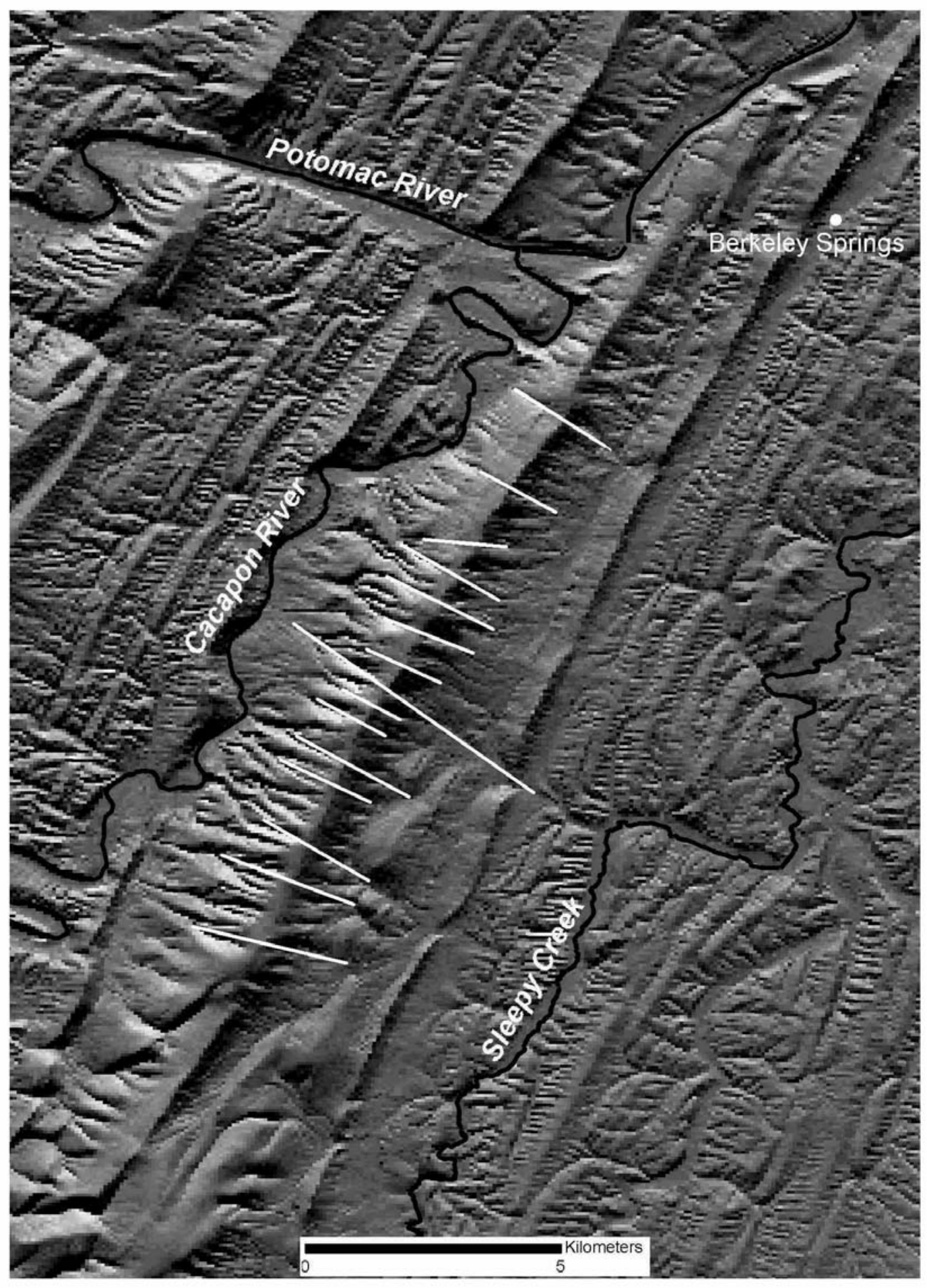

Figure 20. Digital elevation model of Cold Run Valley, Lineaments traced in white. 
drainage channels throughout the summer months. These discharges are a major source of water in times of limited precipitation.

In the Valley and Ridge physiographic province, resistant ridges often confine strike-parallel streams to lowland valleys between them. This occurs in Sir Johns Run. However, Rock Gap and Breakneck runs both have a trellis drainage pattern perpendicular to the valley-bounding ridges and exit the valley through water gaps. This trellis drainage pattern is aligned parallel to the strike-normal fractures crossing Cacapon Mountain.

\section{$\underline{4.62}$ Seepage run along Rock Gap Run}

A seepage run was done along an unnamed northern tributary of Rock Gap Run that measures roughly $1000 \mathrm{~m}$ in length (labeled "Trib \#1" on Figure 21). This stream channel is rocky and extensively braided. Flow either gains or loses when crossing bouldery sections. In one location, between the fourth and fifth measuring point moving down stream, nearly a quarter of the flow drains into a sinkhole. Moving downstream from the headwaters flow generally increased (Table 3). Flows on the tributary ranged from 0.13 to $0.8 \mathrm{cfs}$ before joining a larger tributary discharging $3.42 \mathrm{cfs}$ (labeled Trib \#2 on Figure 21). Three more flow measurements were taken at $150 \mathrm{~m}$ intervals after the confluence of the two tributaries. The flow in this reach increased from 4.23 to $5.88 \mathrm{cfs}$. The elevation difference between the first and final stations is $112 \mathrm{~m}$.

The second seepage run was conducted to measure any major sinks or gains along the entire Rock Gap Run watershed. This seepage run started at high-elevation springs coming off the base of the mountain and measured flows on the confluences of all tributaries (Figure 22). The purpose of this was to note any major losses or gains. 
Table 3. Flow measurements during seepage run on Rock Gap Run.

\begin{tabular}{ccccc}
\hline Seepage Run & Trib 1 & Gains/Losses & Trib 2 & Gains/Losses \\
& Flow (cfs) & Flow (cfs) & Flow (cfs) & Flow (cfs) \\
\hline 1 & 0.13 & 0.47 & 3.68 & -0.26 \\
2 & 0.6 & 0.05 & 3.42 & 1.89 \\
3 & 0.65 & 0.14 & 5.31 & 0.2 \\
4 & 0.79 & -0.14 & 5.51 & 0.37 \\
5 & 0.65 & 0.08 & 5.88 & \\
6 & 0.73 & 0.07 & & \\
7 & 0.8 & 3.48 & & \\
8 & 4.28 & 1.23 & & \\
9 & 5.51 & 0.37 & & \\
10 & 5.88 & & & \\
\hline
\end{tabular}




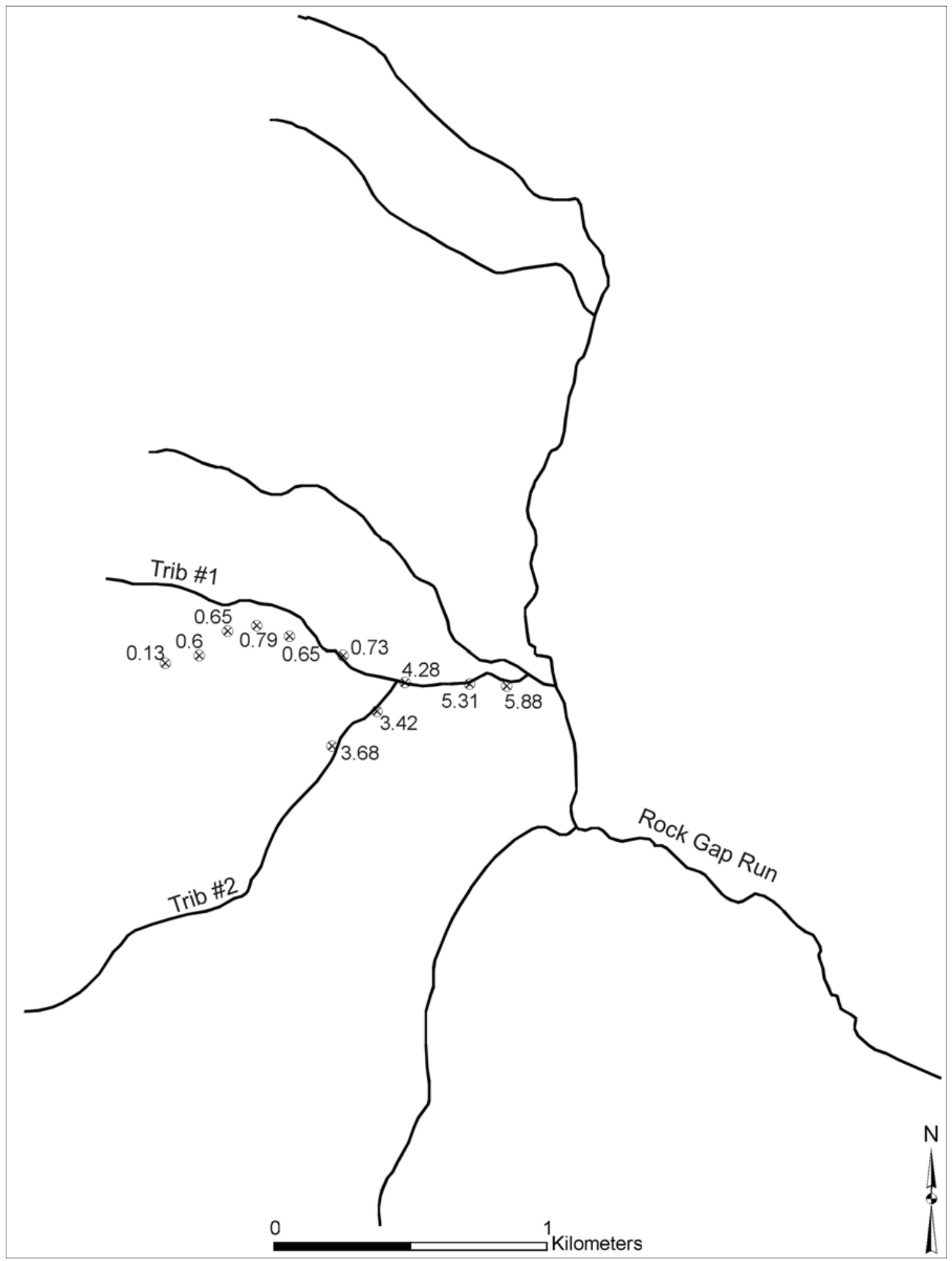

Figure 21. Rock Gap Run tributary seepage run. 


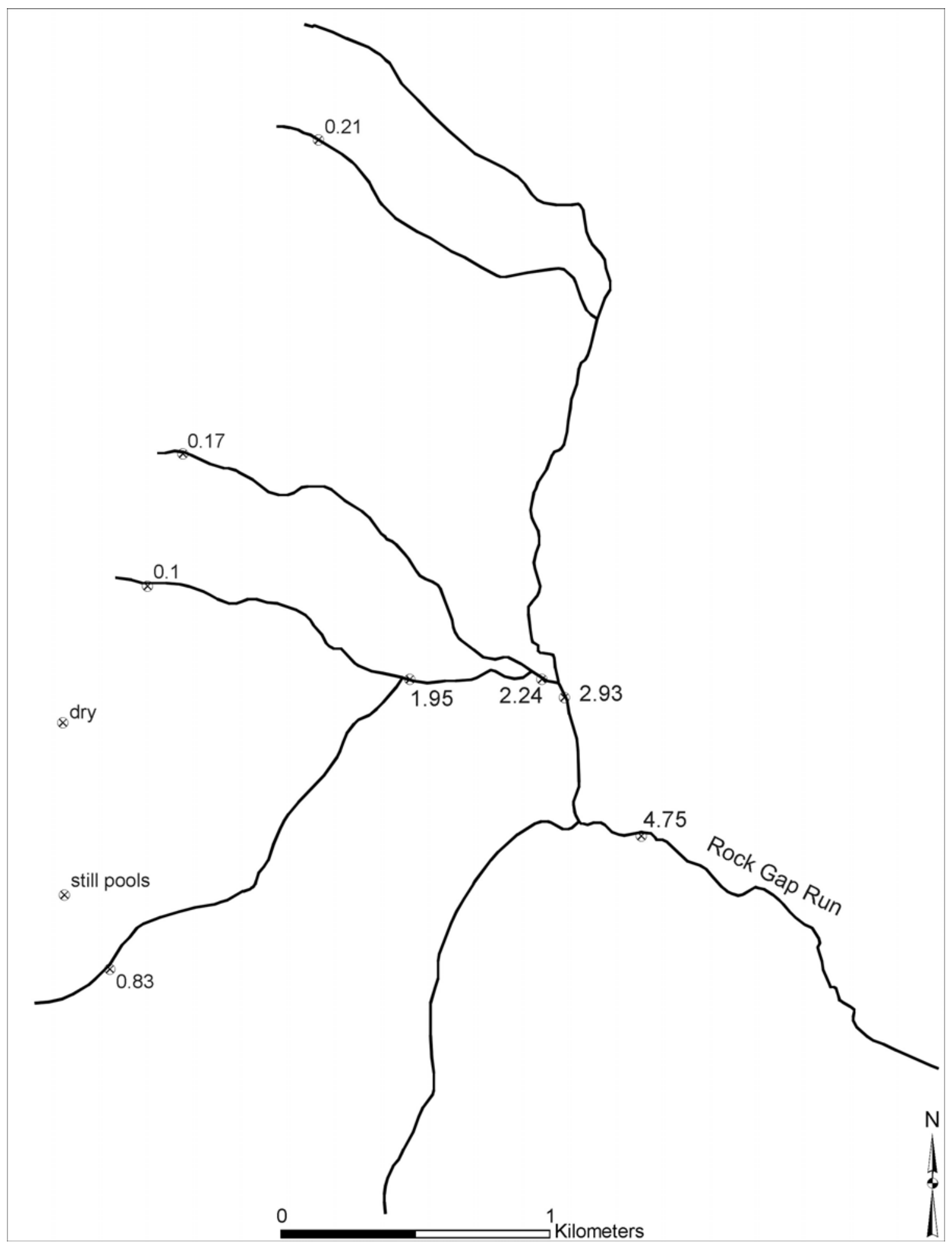

Figure 22. Results of seepage run performed on April $25^{\text {th }}$ 2007on Rock Gap Run. 
Although both springs and sinks were observed, no major losses or gains were measured. Flows ranged from $0.1 \mathrm{cfs}$, at the springs near the top of Cacapon Mountain, to $4.75 \mathrm{cfs}$ at the Rock Gap Run gaging station. The stream gained flow in a downstream direction. The elevation difference between the first and final measuring point is $131 \mathrm{~m}$. 


\section{Analysis}

\subsection{Hydrograph analysis}

Statistical analysis was done to see if the recharge rates for the three montane streams in Cold Run Valley are significantly different than other streams in the Appalachian Mountains. Twenty streams from the Valley and Ridge physiographic province in WV, VA, PA, and MD were selected for comparison (Figure 23). Daily average discharge data from the USGS between July 2006 and July 2007 was used to estimate recharge using RORA. A dataset was compiled including recharge rate, average precipitation, normalized recharge, elevation above sea level, and general geology (Table 4). Normalized recharge was calculated by dividing the recharge rate by average annual precipitation.

Test 1 compared the means of normalized recharge between the Cold Run Valley streams and other streams in the Valley and Ridge. The test employed the T distribution for comparing means of two samples of unequal variance. It may be inferred from the test result (Table 5) that the two sample means are significantly different at a 95\% confidence level.

Test 2 was done on just the streams in the Valley and Ridge, setting upper and lower confidence limits on the normalized recharge data (Table 6). Both year 2007 means of the strike-normal drainages of this study (Rock Gap and Breakneck Run) fell outside these confidence limits, while 2007 normalized recharge of Sir Johns Run fell within the limits. This suggests that, for 2006-2007, Sir Johns Run was not significantly different from the other streams in the Valley and Ridge, but Rock Gap and Breakneck Run were. 


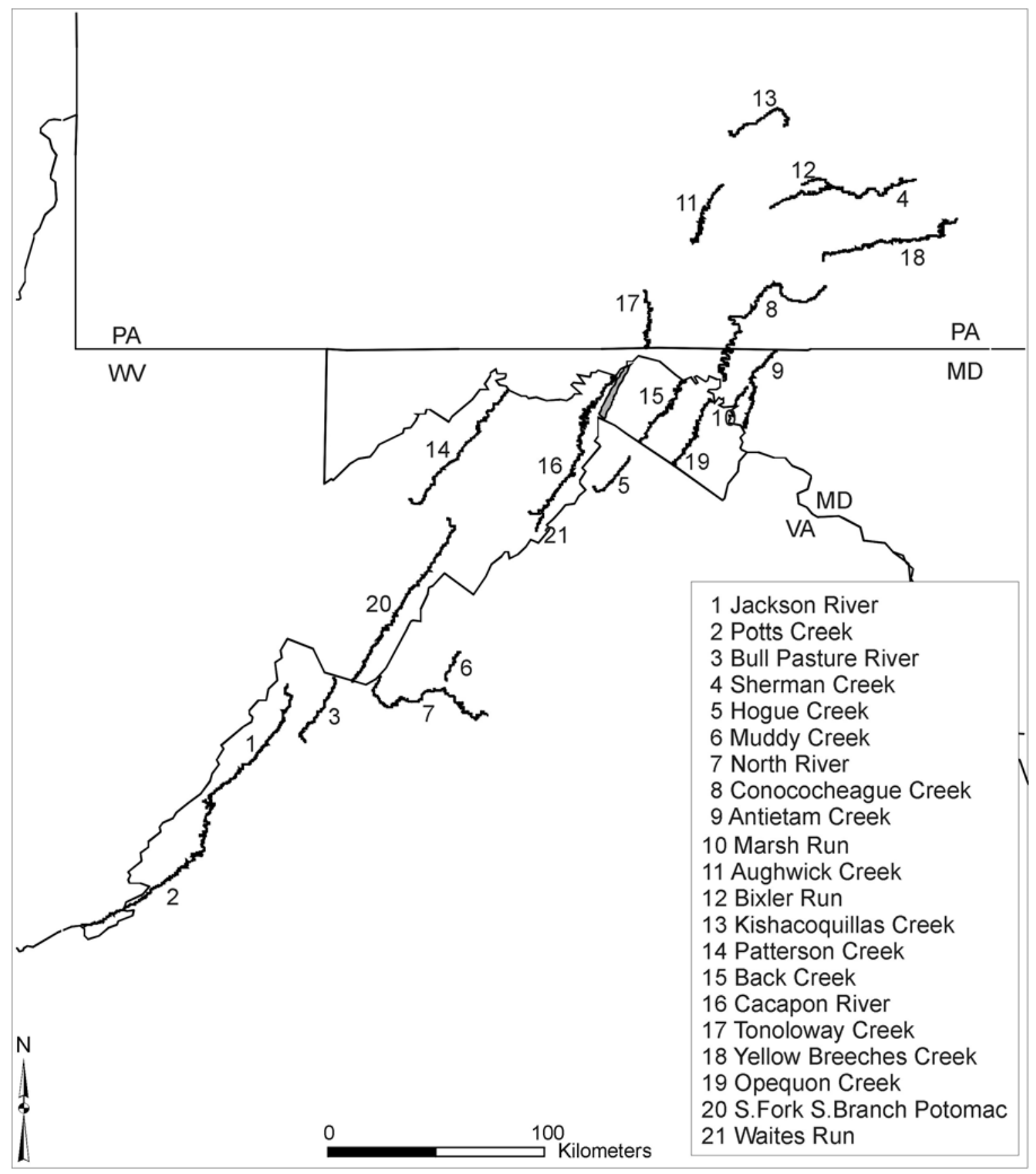

Figure 23. Streams in the Valley and Ridge physiographic province used for statistical comparison. 
Table 4. Baseline data for streams in the Valley and Ridge physiographic province.

\begin{tabular}{|c|c|c|c|c|c|c|}
\hline Stream & Drainage Area (mi2) & Recharge (in/yr) & Average Precipatation (in/yr) & Normailized Recharge & Elevation (ft) & General Geology \\
\hline Cacapon River at Great Cacapon, WV & 675 & 8.35 & 38.9 & 0.21 & 457 & Silurian-Devonian \\
\hline Patterson Creek near Headsville, WV & 211 & 9.18 & 35.7 & 0.26 & 625 & Silurian-Devonian \\
\hline Back Creek near Jones Spring, WV & 235 & 11.34 & 39.39 & 0.29 & 416 & Silurian-Devonian \\
\hline Opequon Creek near Martinsburg, WV & 273 & 10.76 & 39.39 & 0.27 & 355 & Cambrian-Ordovician \\
\hline F. S. Branch Potomac River near Moorefield, V & 277 & 7.98 & 32.87 & 0.24 & 862 & Silurian-Devonian \\
\hline Waites Run near Wardensville, WV & 11.6 & 17.56 & 35.33 & 0.50 & 1250 & Silurian-Devonian \\
\hline Marsh Run at Grimes, MD & 18.9 & 7.91 & 39.45 & 0.20 & 355 & Cambrian-Ordovician \\
\hline Antietam Creek near Sharpsburg, MD & 281 & 12.09 & 40.4 & 0.30 & 311 & Cambrian-Ordovician \\
\hline Conococheague Creek at Fairview, MD & 494 & 10.77 & 39.45 & 0.27 & 392 & Cambrian-Ordovician \\
\hline Tonoloway Creek near Needmore, PA & 10.7 & 10.74 & 38.06 & 0.28 & 689 & Silurian-Devonian \\
\hline Aughwick Creek near Three Springs, PA & 205 & 9.05 & 38.25 & 0.24 & 619 & Silurian-Devonian \\
\hline Sherman Creek at Shermans Dale, PA & 200 & 12.56 & 40.76 & 0.31 & 423 & Silurian-Devonian \\
\hline Kishacoquillas Creek at Reedsville, PA & 164 & 16.02 & 40.85 & 0.39 & 551 & Cambrian-Ordovician \\
\hline Bixler Run near Loysville, PA & 15 & 10.30 & 41.82 & 0.25 & 601 & Silurian-Devonian \\
\hline Yellow Breeches Creek near Camp Hill, PA & 216 & 15.44 & 41.45 & 0.37 & 305 & Cambrian-Ordovician \\
\hline Bullpasture River at Williamsville, VA & 110 & 17.42 & 42.91 & 0.41 & 1610 & Silurian-Devonian \\
\hline Jackson River near Bacova, VA & 157 & 13.41 & 42.91 & 0.31 & 1639 & Silurian-Devonian \\
\hline North River near Stokesville, VA & 17.3 & 21.15 & 36.12 & 0.59 & 2051 & Silurian-Devonian \\
\hline Muddy Creek at Mount Clinton, VA & 14.3 & 9.23 & 36.12 & 0.26 & 1320 & Cambrian-Ordovician \\
\hline Hogue Creek near Hayfield, VA & 15.9 & 8.78 & 36.4 & 0.24 & 669 & Silurian-Devonian \\
\hline Potts Creek near Covington, VA & 153 & 11.56 & 37.23 & 0.31 & 1274 & Silurian-Devonian \\
\hline Sir Johns Run & 8.27 & 13.32 & 38.06 & 0.35 & & Silurian-Devonian \\
\hline Rock Gap Run & 4.18 & 4.29 & 38.06 & 0.11 & & Silurian-Devonian \\
\hline Breakneck Run & 2.55 & 8.95 & 38.06 & 0.24 & & Silurian-Devonian \\
\hline
\end{tabular}


Table 5. Results of a T-Test comparing the means of the normalized recharge between streams in Cold Run Valley and comparison streams from the Valley and Ridge.

\begin{tabular}{ccc}
\hline & Cold Run Valley & Streams in V and R \\
\hline $\mathrm{n}$ & 3 & 21 \\
Mean & 0.23 & 0.31 \\
Standard Deviation & 0.12 & 0.09 \\
Standard Error & 0.07 & 0.02 \\
Degree of freedom & 2 & 20 \\
$\mathrm{X}_{1-2}$ & -18 & \\
Standard Error ${ }_{1-2}$ & 4.37 & \\
$\mathrm{~T}_{1-2}$ & 4.12 & \\
$\mathrm{~T}_{\text {crit }}$ & 2.07 & \\
& & $\mathrm{R}$ \\
Since $\mathrm{T}$ is greater than $\mathrm{T}_{\text {crit }} \mathrm{H}_{\mathrm{o}}$ is rejected & & \\
$\mathrm{H}_{\mathrm{o}}$ & $\mathrm{u} 1=\mathrm{u} 2$ & \\
\hline
\end{tabular}


Table 6. T-Test results for the upper and lower confidence limits of normalized recharge for comparison streams from the Valley and Ridge.

\begin{tabular}{cc}
\hline $\mathrm{n}$ & 21 \\
Mean: & 0.31 \\
Standard Deviation: & 0.09 \\
Standard error: & 0.02 \\
Degree of Freedom & 20 \\
T (95\%) & 2.09 \\
Lower Confidence Limit & 0.27 \\
Upper Confidence Limit & 0.35 \\
At $\mathrm{p}(95 \%)$ & $0.266<\mathrm{t}<0.352$ \\
\hline
\end{tabular}


A third t-test was done comparing the means of normalized recharge between the strike normal streams in Cold Run Valley and the other streams in the Valley and Ridge. The test shows that the means are significantly different (Table 7); removing Sir Johns Run from the Cold Run Valley dataset increased the gap between the means of the two groups.

The normalized recharge for the sampled streams from the Valley and Ridge was plotted along with the normalized recharge numbers from Cold Run Valley (Figure 24). Breakneck and Sir Johns runs both fall within the range of normalized recharge for the Valley and Ridge streams but neither fall between the first and third quartile. Rock Gap Run falls well below the range of normalized recharge for the Valley and Ridge Streams.

The large majority of the Valley and Ridge streams chosen for comparison are strike-parallel. One possible reason that Breakneck Run and Rock Gap Run differ in recharge rate from these other streams is that they are strike-normal, and hence cross the upper Silurian carbonate units perpendicular to the strike of these units.

Differences in the composition of the total flow might be explained by the characteristics of each watershed. Sir Johns Run is underlain by relatively little limestone and only in its upper $3 \mathrm{~km}$ of reach; it also does not flow directly over the conduitforming Helderberg limestone. In comparison to other nearby watersheds (Cacapon River, Patterson Creek, and Back Creek), Sir Johns Run has similar flow component proportions (Table 8). On average the streams used for comparison were comprised of $50 \%$ baseflow, 20\% quickflow, and $30 \%$ runoff. Sir Johns Run is the largest watershed in the aquifer, and therefore its measuring station is furthest from the headwaters. 
Table 7. Results of a T-Test comparing the means of the normalized recharge between the strike normal streams in Cold Run Valley and the sample streams from the Valley and Ridge.

\begin{tabular}{ccc}
\hline & Strike Normal Streams & Streams in V and R \\
\hline $\mathrm{n}$ & 2 & 21 \\
Mean & 0.17 & 0.31 \\
Standard Deviation & 0.09 & 0.09 \\
Standard Error & 0.06 & 0.02 \\
Degree of freedom & 1 & 20 \\
$\mathrm{X}_{1-2}$ & -19 & \\
Standard Error & 4.37 & \\
$\mathrm{~T}_{1-2}$ & 4.35 & \\
$\mathrm{~T}_{\text {crit }}$ & 2.08 & \\
& & \\
Since $\mathrm{T}$ is greater than $\mathrm{T}_{\text {crit }} \mathrm{H}_{\mathrm{o}}$ is rejected & & $\mathrm{REJECTED}$ \\
$\mathrm{H}_{\mathrm{o}}$ & $\mathrm{u} 1=\mathrm{u} 2$ &
\end{tabular}




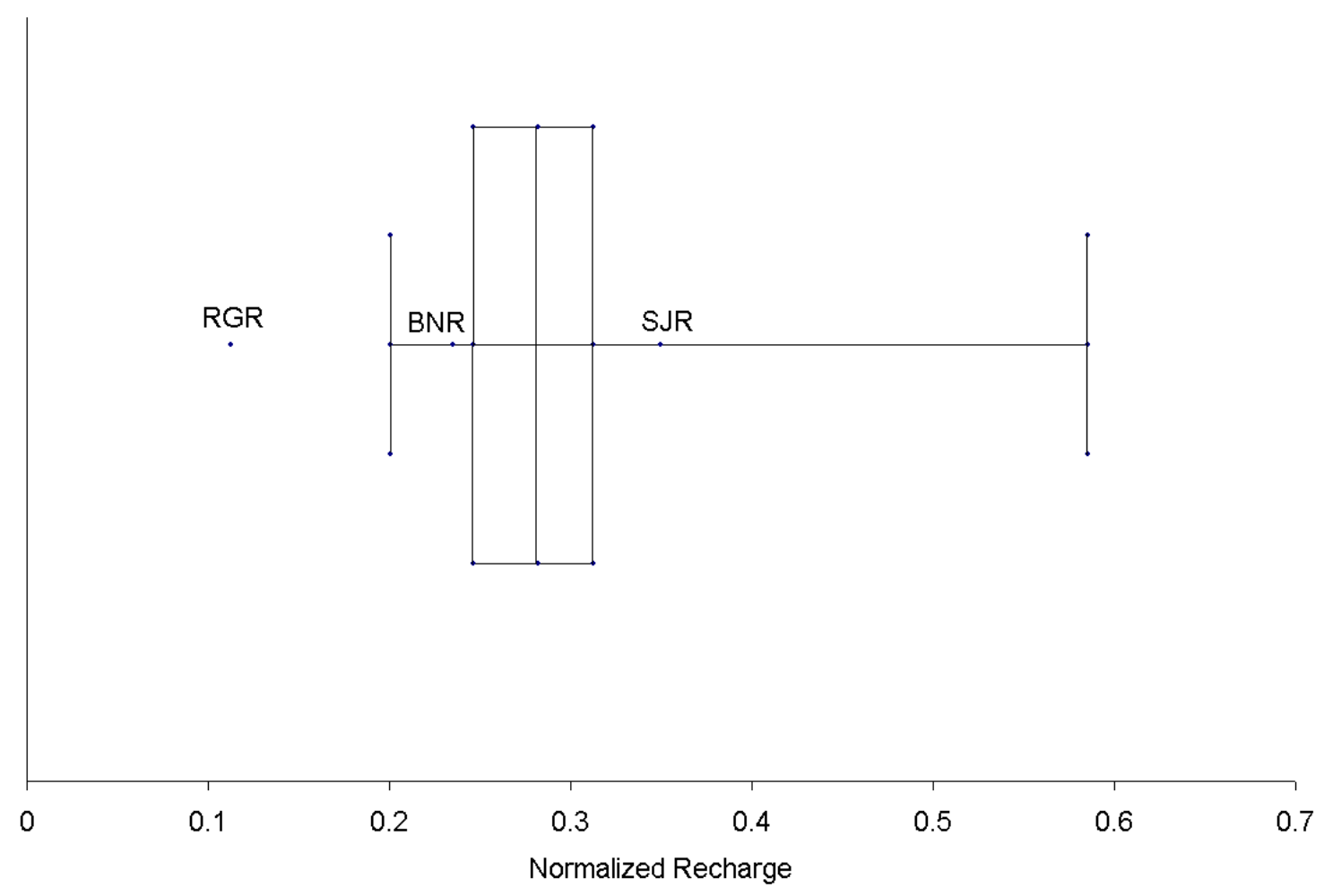

Figure 24. Whisker plot of normalized recharge values for sample streams in the Valley and Ridge showing relationship of study area streams. Legend: RGR = Rock Gap Run, BNR = Breakneck Run, SJR = Sir Johns Run. 
Table 8. Flow proportions for streams in West Virginia's eastern panhandle.

\begin{tabular}{ccccccc}
\hline & Sir Johns Run & Breakneck Run & Rock Gap Run & \multicolumn{4}{c}{ Back Creek Patterson Creek Cacapon River } \\
\hline Total Flow (in) & 18.51 & 7.36 & 5.60 & 13.44 & 9.24 & 11.63 \\
Total Baseflow (in) & 9.85 & 5.81 & 1.63 & 7.21 & 5.50 & 3.84 \\
Total Runoff (in) & 5.21 & 0.79 & 3.08 & 3.16 & 3.07 & 4.58 \\
Total Quickflow (in) & 3.46 & 0.76 & 0.89 & 3.08 & 0.67 & 3.21 \\
\hline
\end{tabular}


Baseflow on Breakneck run accounts for more that $75 \%$ of the total flow leaving the aquifer (Table 8). Combined quickflow and runoff only account for about $20 \%$ of the total flow (Table 8). This high proportion of baseflow suggests that some runoff may be being lost to exfiltration. Extensive boulder fields make up large portions of the catchment area at Breakneck Run that may accommodate exfiltration. If the exfiltration does reach the channel, it does so downstream of the measuring point.

Rock Gap Run's total flow is slightly more than half runoff. This stream responds to and recovers from a storm faster than the other streams draining the aquifer. The fraction of total flow discharging as baseflow to Rock Gap Run is significantly less than the other streams in the aquifer. During dry periods in 2007, the stream nearly dried up completely. Groundwater discharge in this watershed may be lower than that of surrounding watersheds due to water loss either by infiltration/deep underflow or by lateral flow to another watershed.

\subsection{Methods for recharge rate estimation}

The integration techniques are more straightforward than the other techniques performed. The difference between the MB and DS is small but significant. The recharge calculated with the MB technique does not include quickflow. Therefore, it underestimates the amount of recharge to karst aquifers if a quickflow component is present. The numeric integration technique only excludes storm runoff from the calculation, so quickflow is included in the recharge estimation.

All of the methods for obtaining recharge from streamflow, besides DS, were designed for situations in which a gaging station is located near the mouth of the stream or river on a gentler gradient. In this study the gaging stations are located in the 
headwaters adjacent to the recharge source. Stormflow events move through within a couple of hours and are easily separated out visually. Hydrographs of streams in the headwaters have a pronounced response to storm events. These reasons suggest that the most accurate method for estimating recharge in this study is Direct Separation.

\subsection{Local spatial variations in recharge rate}

In Cold Run Valley, two strike normal drainages cross the Helderberg (Breakneck and Rock Gap Run) and one strike-parallel drainage (Sir Johns Run) does not. Strike normal drainages in Cold Run Valley average less than 50\% area-normalized recharge of the strike parallel drainage. The differences in recharge could be attributed to several factors.

The Sir Johns Run watershed is underlain by the least amount of carbonate bedrock, by percent area. Its channel is also the only one of the three that does not flow directly over the Helderberg formation influencing recharge rates. The watersheds with streams that flow over the Helderberg have significantly lower recharge rates. The recharge rates could be lower due to water loss on Rock Gap or Breakneck Run that either resurfaces further downstream of the measuring point or is lost to deep underflow. Sir Johns Run is the largest watershed in the study area. It would be convenient to say that the larger the watershed the higher the recharge rate, but the calculated recharge for the other two watersheds could be incorrect due to water losses so that conclusion cannot be made.

Recharge rates on Rock Gap Run were significantly lower than for the other streams in the study area. This suggests that Rock Gap Run may be a losing stream, and 
that the apparent recharge rate is not close to the actual recharge rate, which is underestimated by the streamflow integration methods as a result of stream losses.

It is possible that the lower recharge rate may be in part an artifact caused by an error in the assumption that the groundwater divide between Rock Gap Run and Indian Creek coincides with their surface drainage divide. Cacapon State Park, located in the Indian Run watershed, pumped two high yield wells a combined amount of 22 to 38 thousand gallons per day on weekdays and 38 to 53 thousand gallons per day on weekends in 2006. This equates to about 0.3 inches of water over the Rock Gap Run watershed. The pumping may cause some shift in the groundwater divide, diverting recharge from the Rock Gap watershed.

Water could also be lost to a deeper flow path recharging a distant spring. The recharge area for the springs at Berkeley Springs is not known. It has been found that the chemistry of the springs at Berkeley Springs is the same as the chemistry of the springs within Cold Run Valley (Donovan et al., 2006). It is possible that the water lost from Rock Gap Run could be recharging Berkeley Springs.

The recharge rate for Breakneck Run is similar to average recharge rates of the comparison streams, Patterson Creek, Back Creek, and the Cacapon River. Because Breakneck Run's recharge area is in a montane setting, its recharge rate would be expected to be higher than "normal" due to increased snow pack and decreased evapotranspiration. The apparent recharge rate estimated for Breakneck Run could be lower than expected due to the location of the measuring point. During periods of high flow, a portion of the water is diverted to a secondary channel. Therefore, downstream of 
the measuring point, a tributary enters during high flow conditions that is not included in the recharge or drainage area calculation. Losses to underflow may also be taking place.

\subsection{Comparison of recharge rates to other aquifers in the humid east}

The recharge rates estimated for Rock Gap Run and Breakneck Run both may be inaccurate due to stream losses. Therefore, only the recharge rate for Sir Johns Run was compared to other selected watersheds in the humid east (Cacapon River, Back Creek, and Patterson Creek). The recharge for Sir Johns Run was between three and six inches higher than the recharge in the surrounding watersheds in West Virginia's Eastern Panhandle. This may be due to the fact that the recharge catchment of Sir Johns Run is in a montane setting while the comparison streams are mainly in lowland settings.

\subsection{Recharge Mechanics of the Aquifer}

\section{$\underline{5.51 \text { Structural and Geomorphic effects }}$}

The quickflow portions of the stream hydrographs in Cold Run Valley could be associated with the delayed flow discharging from the colluvial deposits. The storage capacity of these colluvial deposits would tend to increase recharge rates; water that would have otherwise been lost as storm runoff may be intercepted as recharge to these deposits, draining to streams later in the year.

The strike-normal Rock Gap Run and Breakneck Run sections could both have lower recharge rates because they are losing water to the fracture associated with the lineaments that formed perpendicular to the Cacapon Mountain anticline. Such fractures normal to folds tend to be open (Pollard, 2005) and are likely to be more permeable than fractures of other orientations. 


\subsection{Limitations-Future Investigation}

One obvious limitation of this study is the short duration of streamflow data. Continued monitoring at the gaging stations over a longer period of time will give a better idea of the long-term recharge rates.

Further study of the bouldery deposits in the area would be helpful in obtaining a better overall cross section of the aquifer and Cold Run Valley. Continued monitoring of the stream and installation of more data loggers in the boulder fields to observe flow paths continuously would also be helpful in understanding the true effect the deposits have on the recharge mechanics.

A detailed groundwater model of the aquifer, especially of the Rock Gap Run watershed might illuminate further where the water lost at Rock Gap Run and Breakneck Run is emerging. 


\section{Conclusions}

Major conclusions of this research are that:

1) For the 2006-2007 water year two of the streams in this study (Rock Gap Run and Breakneck Run) had significantly lower apparent recharge rates than the third stream (Sir Johns Run). Apparent recharge rates of the strike parallel and strike normal streams of this study may differ systematically. In 2007, the strike parallel stream (Sir Johns Run) had higher recharge rates than strike normal streams (Rock Gap Run and Breakneck Run) due to water losses in the latter associated with the fractures. Normalized recharge rates from these strike normal streams are also significantly different from a sample of strike-parallel streams used for comparison in the Valley and Ridge.

2) Estimating recharge rates from streamflow may give inaccurate results if the channel flows over highly transmissive conduit forming or fractured limestone. Stream losses upstream of the gaging station will induce lower apparent recharge rate estimates.

3) Quickflow can be an important component of recharge. To estimate recharge from stream flow records the topography and lithology of the watershed should be considered. For gages located in the headwaters of small limestone watersheds in the humid eastern United States quickflow can be an important component of recharge. Therefore, methods that project baseflow back, cutting out the quickflow portion of the hydrograph may underestimate recharge in these watersheds. 


\section{References}

Atkinson, T.C., 1977. Diffuse flow and conduit flow in limestone terrain in the Mendip Hills, Somerset (Great Britain). Journal of Hydrology, 35(1-2): 93-110.

Broughton, C.J., McCoy, K.J, 2006. Hydrogeology, aquifer geochemistry, and groundwater quality in Morgan County, West Virginia. U.S. Geological Survey Scientific Investigation Report 2006-5198.

Chen, W.P., and Lee, C.H., 2003. Estimating ground-water recharge from streamflow records. Environmental Geology, 44: 257-265.

Dean, S.L., P. Lessing, B.R. Kulander, and D.W. Hawley, 1995. Geology of the Hancock Quadrangle, Morgan County, WV. West Virginia Geologic and Economic Survey Open-File Report OF9503.

Donovan, J.J., Vesper, D., Corder, L., Werner, E., 2006. Springs, source water areas, and potential for high-yield aquifers along the Cacapon Mountain anticline, Morgan County, WV. HRC report: 42p.

Downey, J.S., 1984. Geohydrology of the Madison and Associated Aquifers in Parts of Montana, North Dakota, South Dakota, and Wyoming. U.S. Geological Survey Professional Paper 1273-G: 44p.

Felton, G.K., Currens, C.C., 1994. Peak flow rate and recession-curve characteristics of a karst spring in the Inner Bluegrass, central Kentucky. Journal of Hydrology, 162: 99-118.

Fenneman, N.M., 1928. Physiographic Divisions of the United States. Annals of the Association of American Geographers, 18: 264-313.

Ford, D.C., 1983. Alpine Karst Systems at Crowsnest Pass, Alberta-British Columbia, Canada. Journal of Hydrology, 61:187-192.

Grimsley, G.P., 1916. Jefferson, Berkeley, and Morgan counties, West Virginia Geologic Survey County Report.

Halihan, T., Wicks, C.M., Engeln, J.F., 1998. Physical response on a karst drainage basin to flood pulses: example the Devil's Icebox cave system (Missouri, USA). Journal of Hydrology, 204: 24-36. 
Hanson, R.L., 1991. Evapotranspiration and Droughts. U.S. Geological Survey WaterSupply Paper 2375: 99-104.

Ketchum, J.N., Donovan, J.J., and W. H. Avery, 2000. Recharge characteristics of a phreatic aquifer as determined by storage accumulation. Hydrogeology Journal, 8: 579-593.

Keller, A.E., 2000. Environmental Geology 8th ed. Prentice-Hall Inc, Upper Saddle River, NJ.

Kozar, M.D., and Mathes, M.V., 2001. Aquifer-characteristics data for West Virginia. U.S. Geological Survey Water Resources Investigation Report 01-4036: $74 \mathrm{p}$.

Kulander, B.R., P. Lessing, S.L. Dean, and C.S. Kulander, 1995. Geology of the Stotlers Crossroads Quadrangle, Berkeley and Morgan Counties, WV. West Virginia Geologic and Economic Survey Open-File Report OF9504.

Maillet, E., 1905. Essais d'Hydraulique Souterraine et Fluviale. Herman, Paris.

Meyboom, P., 1961. Estimating ground water recharge from stream hydrographs. Journal of Geophysical Research 66(4): 1203-1214.

Minke, J.G., 1964. Geology of the Hancock and Stottlers Crossroads quadrangles in West Virginia, West Virginia University, Morgantown, 41pp.

Padilla, A., Pulido-Bosch, A., and Mangin A., 1994. Relative importance of baseflow and quickflow from hydrographs of karst springs. Ground Water, 32(2): 267277.

Petric, M., 2001. The Role of Accurate Recharge Estimation in the Hydrodynamic Analysis of Karst Aquifers. Acta Carsologica, 30/1: 69-84.

Petric, M., 2004. Alpine Karst Waters in Slovenia. Acta Carsologica, 33/1: 11-24. Pollard, D.D., and Fletcher R.C., 2005. Fundamentals of Structural Geology. Cambridge University Press, New York, 497 pp.

Ramirez, J.A., 2000. Prediction and Modeling of Flood Hydrology and Hydraulics. In: E. Wohl (Editor), Inland Flood Hazards: Human, Riparian and Aquatic Communities. Cambridge University Press, Cambridge. 
Rorabaugh, M.I., 1964. Estimating changes in bank storage and groundwater contibutions to streamflow. International Association of Science Hydrology, 63: 432441.

Rutledge, A.T., and Daniel, C.C., 1994. Testing an automated method to estimate ground-water recharge from stream records. Ground Water, 32(2): 180-189.

Rutledge, A.T., and Mesko, T.O., 1996. Estimated hydrologic characteristics of shallow aquifer systems in the Valley and Ridge, the Blue Ridge, and the Piedmont Physiographic Provinces based on analysis of streamflow recession and base flow. U.S. Geological Survey Professional Paper 1422-B.

Rutledge, A.T., 1998. Computer Programs for describing the recession of ground-water discharge and for estimating mean ground-water recharge and discharge from streamflow records-update. U.S. Geological Survey Water-Resource Investigation Report 98-4148: 43p.

Rutledge, A.T., 2000. Considerations for use of the RORA program to estimate groundwater recharge from stream flow records. U.S. Geological Survey Open-File Report 00-156: 44p.

Spatial Climate Analysis Service, 2000. Average Annual Precipitation West Virginia. Oregon State University.

Swain, L.A., Hollyday, E.F., Daniel, C.C., III, and Zapecza, O.S., 1991. Plan of study for the regional aquifers system analysis of the Appalachian Valley and Ridge, Piedmont, and Blue Ridge Physiographic Provinces of the Eastern and Southeastern United States, with a description of the study-area Geology and Hydrology. U.S. Geological Survey Water-Resource Investigation Report 91-4066: 44p.

Swain, L.A., 1993. Hydrogeological Characteristics of the Bedrock Aquifers in the Appalachian Valley and Ridge, Piedmont, and Blue Ridge Physiographic Provinces of the Eastern and Southeastern United States. Bulletin of the American Association of Petroleum Geologists, 77-78: 1476.

Szilagyi, J., 1999. On the use of semi-logarithmic plots for baseflow separation. Ground Water, 37(5): 660-662. 
Vogel, R.M., Kroll, C.N., 1996. Estimation of Baseflow Recession Constants. Water Resources Management, 10: 303-320.

White, W.B., 1998. Geomorphology and Hydrology of Karst Terrains. Oxford Press, New York, 460-465 pp. 


\section{Plate 1. Geology and hydrology of the Cacapon Mountain aquifer}
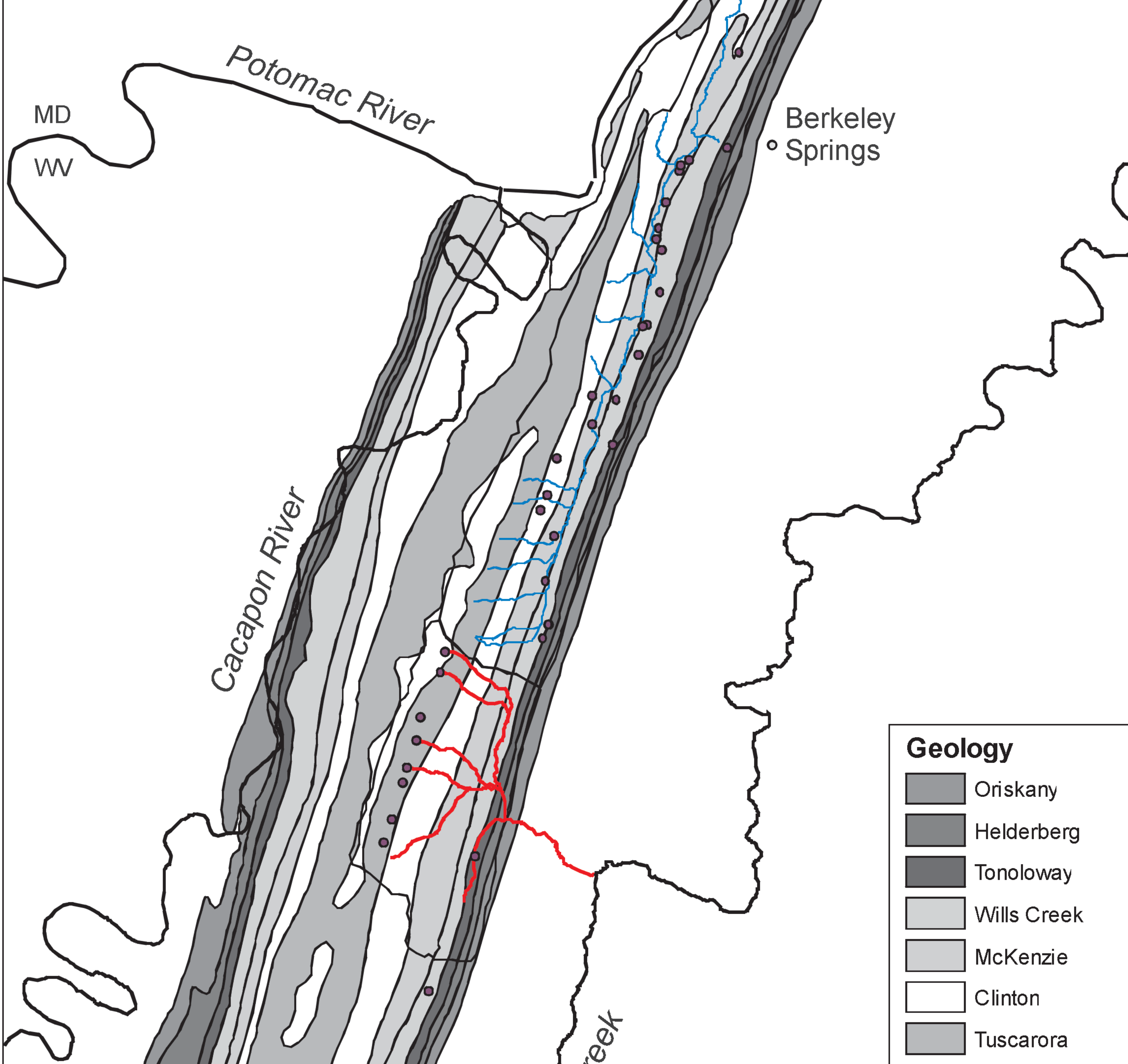